\title{
HUMAN CARTILAGINOUS ENDPLATE DEGENERATION IS INDUCED BY CALCIUM AND THE EXTRACELLULAR CALCIUM-SENSING RECEPTOR IN THE INTERVERTEBRAL DISC
}

\author{
M.P. Grant ${ }^{1}$, L.M. Epure ${ }^{1}$, R. Bokhari ${ }^{1,3}$, P. Roughley ${ }^{2}$, J. Antoniou ${ }^{1}$ and F. Mwale ${ }^{1 *}$ \\ ${ }^{1}$ Lady Davis Institute for Medical Research, SMBD-Jewish General Hospital, and Department of Surgery, McGill \\ University, Montreal, Canada \\ ${ }^{2}$ Genetics Unit, Shriners Hospital for Children, and Department of Surgery, McGill University, Montreal, Canada \\ ${ }^{3}$ Division of Neurosurgery, Department of Surgery, King Abdulaziz University, Jeddah, Kingdom of Saudi Arabia
}

\begin{abstract}
The cartilaginous endplates (CEPs) are thin layers of hyaline cartilage found adjacent to intervertebral discs (IVDs). In addition to providing structural support, CEPs regulate nutrient and metabolic exchange in the disc. In IVD pathogenesis, CEP undergoes degeneration and calcification, compromising nutrient availability and disc cell metabolism. The mechanism(s) underlying the biochemical changes of CEP in disc degeneration are currently unknown. Since calcification is often observed in later stages of IVD degeneration, we hypothesised that elevations in free calcium $\left(\mathrm{Ca}^{2+}\right)$ impair CEP homeostasis. Indeed, our results demonstrated that the $\mathrm{Ca}^{2+}$ content was consistently higher in human CEP tissue with grade of disc degeneration. Increasing the levels of $\mathrm{Ca}^{2+}$ resulted in decreases in the secretion and accumulation of collagens type I, II and proteoglycan in cultured human CEP cells. $\mathrm{Ca}^{2+}$ exerted its effects on CEP matrix protein synthesis through activation of the extracellular calcium-sensing receptor (CaSR); however, aggrecan content was also affected independent of CaSR activation as increases in $\mathrm{Ca}^{2+}$ directly enhanced the activity of aggrecanases. Finally, supplementing $\mathrm{Ca}^{2+}$ in our IVD organ cultures was sufficient to induce degeneration and increase the mineralisation of CEP, and decrease the diffusion of glucose into the disc. Thus, any attempt to induce anabolic repair of the disc without addressing $\mathrm{Ca}^{2+}$ may be impaired, as the increased metabolic demand of IVD cells would be compromised by decreases in the permeability of the CEP.
\end{abstract}

Keywords: Intervertebral disc, degeneration; cartilaginous endplate; calcification; calcium, extracellular calciumsensing receptor; disc nutrition.

*Address for correspondence:

Dr. Fackson Mwale

Lady Davis Institute for Medical Research

Sir Mortimer B. Davis - Jewish General Hospital

3755 Chemin Cote Ste Catherine

Montréal, Canada, H3T1E2

Telephone number: (514)-340-8222 Ext. 2948

Fax number: (514)-340-7502

E-mail: fmwale@jgh.mcgill.ca

\section{Introduction}

Chronic low back pain is a debilitating condition; it diminishes the quality of life, and is one of the most common reasons for seeking health care (Manchikanti et al., 2014). Although there are several factors contributing to low back pain, intervertebral disc (IVD) degeneration is commonly accepted as a principal cause (DePalma et al., 2011; Kjaer et al., 2005; Luoma et al., 2000; Paajanen et al., 1989; Paajanen et al., 1997; Visuri et al., 2005). IVDs are composed of an inner gelatinous nucleus pulposus (NP), and an outer fibrous ring, the annulus fibrosus (AF). Separating the IVD from the vertebral bodies is the cartilaginous endplate (CEP), a thin layer of hyaline cartilage that is in direct contact with the disc, bridging the disc with the vertebral bone (Chan et al., 2011). CEPs not only provide biomechanical support, as they distribute intradiscal pressures and prevent bulging of the nucleus into the neighbouring vertebral body, but are the primary route for nutrient transport between the vertebral capillaries and the IVD cells (Grunhagen et al., 2011). Several models have demonstrated the importance of the CEP in disc nutrition (Grunhagen et al., 2011; Jackson et al., 2011; Kang et al., 2014; Roberts et al., 1996; Shirazi-Adl et al., 2010). CEP undergoes physical changes in the degenerate disc: decreases in the proteoglycan and collagen content, thinning, loss of water, and calcification, hallmarks that parallel the degeneration of the disc (Antoniou et al., 1996; Bernick and Cailliet, 1982; Lotz et al., 2013; Roberts et al., 1993). Alterations in the biochemistry of the CEP have direct effects on nutrient availability in the disc, and its degeneration/calcification is suggested as a precursor to IVD disease (Grunhagen et al., 2011). Although several studies have demonstrated a direct relationship between nutrient supply and disc cell viability, key factors implicated in the onset and progression of disc degeneration (Buckwalter, 1995; Horner and Urban, 2001; Korkiakoski et al., 2009; Kurunlahti et al., 2001; Tokuda et al., 2007; Urban et al., 2004), others have demonstrated an increase in angiogenesis and diffusion in advanced degenerative and herniated discs (Binch et al., 2014; David et al., 2010; Lee et al., 2011; Niinimaki et al., 2009; Rajasekaran et al., 2004). Although a paradox in the hypothesis of nutrient availability and disc degeneration, many of the IVDs that demonstrate increased diffusion often present with degenerative endplate defects and/or Modic changes (Lotz et al., 2013). A compromised endplate may subject the immune privileged disc to inflammatory cytokines and 
immune cells (Risbud and Shapiro, 2014), exacerbating the degenerative process. The mechanism(s) responsible for the degeneration/calcification of the CEP are unclear, although upregulation of aggrecanases (ADAMTS), matrix metalloproteinases (MMPs), type X collagen, alkaline phosphatase (ALP), and inflammatory cytokines such as interleukin-1 $\beta$ (IL-1 $\beta$ ) - implicated in IVD and cartilage degeneration - may be involved (Boos et al., 1997; Chen et al., 2014; Chevalier et al., 2013; Gruber et al., 2014; Risbud and Shapiro, 2014; Zhang et al., 2012).

The extracellular calcium-sensing receptor (CaSR), a family C G-protein coupled receptor (GPCR), is known for its role in regulating parathyroid hormone synthesis and secretion from the parathyroid glands, and is the primary means for sensing extracellular calcium (Brown, 2013). However, CaSR expression is not restricted to the parathyroid glands, as its expression and function have been described in other calcium-handling tissues, including bone, kidney, and gut (Alfadda et al., 2014). High extracellular $\mathrm{Ca}^{2+}$ has been shown to promote the terminal differentiation of chondrocytes and maturation of osteoblasts, and induce mineralisation in culture (Bonen and Schmid, 1991; Chang et al., 1999a; Chang et al., 1999b; Dvorak et al., 2004; Rodriguez et al., 2005). Concordantly, in vitro and in vivo studies using tissue-specific and inducible osteoblast and chondrocyte knockouts of CaSR have provided evidence for an important role in bone and cartilage development (Chang et al., 2010; Chang et al., 2008; Chang et al., 2002; Dvorak-Ewell et al., 2011; Santa Maria et al., 2015; Wu et al., 2004).

Several diseases are directly linked to CaSR (Brown, 2013). For instance, inactivation mutations of the CaSR result in familial hypocalciuric hypercalcemia and neonatal severe hyperparathyroidism, where one or both alleles are affected, respectively, and activating mutations of CaSR result in autosomal dominant hypocalcemia (ADH). Patients with activating mutations of CaSR often develop nephrocalcinosis and renal insufficiency, with a high degree of ectopic calcifications early in life (Brown, 2013). In one notable kindred with $\mathrm{ADH}$, all probands developed premature osteoarthritis (Stock et al., 1999). Animal studies have also demonstrated a link between CaSR activation and disease. For instance, in a guinea pig model of osteoarthritis, CaSR was shown to be upregulated in articular cartilage and its activation accelerated the degeneration and modulated the function of the inflammatory cytokine IL-1 $\beta$ (Burton et al., 2005). In another study, where mice were generated to possess a gain-of-function CaSR mutation, widespread ectopic calcification was observed (Hough et al., 2004). A role for the CaSR in the development or maintenance of other cartilaginous tissues such as the IVD remains unknown. Based on these observations, we hypothesise that increases in local extracellular $\mathrm{Ca}^{2+}$ in the disc microenvironment and activation of CaSR promote degeneration of the CEP.

To address this, we determined the $\mathrm{Ca}^{2+}$ content and expression of the CaSR in human CEP tissue with increasing grades of degeneration and evaluated the role of $\mathrm{Ca}^{2+}$ in regulating the synthesis of matrix proteins, collagens type I, II, and proteoglycans, and aggrecanase activity. In addition, we investigated the role of the CaSR in CEP tissue integrity. To our knowledge, this is the first study to describe a mechanism for the degeneration and calcification of the CEP, and the involvement of a GPCR in the pathology of the disc.

\section{Materials and Methods}

\section{Antibodies and materials}

Anti-CaSR antibody [5C10, ADD] (Cat\# ab19347), anticollagen I and anti-collagen II antibodies (Cat\# ab34710 and ab34712, respectively), anti-ADAMTS-4 and -5 (Cat\# ab111905 and ab41037, respectively), anti-MMP-13 (Cat\# ab39012), and anti-ALP antibody (Cat\# ab95462) were purchased from Abcam, Toronto, Canada. Anti-G1 aggrecan antibody was generated by Dr. Peter Roughley (Roughley and Mort, 2012). Cinacalcet hydrochloride (CaSR agonist, Cat\# C441800) was purchased from Toronto Research Chemicals, Toronto, Canada; and CaSR antagonist (CaSR antagonist 18c, Cat\# Axon 1732) from Axon Medchem, Reston, VA.

\section{Source of human tissue}

Human thoracolumbar spines were harvested through the organ donation program of Hema-Québec within $12 \mathrm{~h}$ of death. Donors that had had recent chemotherapy, radiation therapy to the spine, or significant long-standing paralysis were excluded from the study. CEP tissue was obtained from lumbar discs with different Thompson scores (Thompson et al., 1990) from eight donors (age range of 18 to 65 years). All procedures were approved by the institutional review board of the Jewish General Hospital.

Calcium concentration in human cartilage endplates CEPs were digested overnight at $56{ }^{\circ} \mathrm{C}$ with Proteinase $\mathrm{K}$ (Bio Basic, Canada) in Proteinase $\mathrm{K}$ buffer $(50 \mathrm{mM}$ Tris- $\mathrm{HCl}, \mathrm{pH}$ 7.4). Samples were centrifuged and the supernatant was assayed for $\mathrm{Ca}^{2+}$ content using a calcium detection kit following the manufacturer's guidelines (Abcam, Toronto, Canada).

\section{Immunohistochemistry and staining}

CEP tissue was fixed in Accustain (Sigma-Aldrich, St. Louis, MO), paraffin embedded, and $5 \mu \mathrm{m}$ sections were prepared on slides. Sections were rehydrated prior to immunohistochemistry or staining by deparaffinisation in xylene followed by sequential incubation in decreasing concentrations of alcohol and water. All sections prior to antibody incubation were treated with BLOXALL (Vector Laboratories, Burlingame, CA) for $10 \mathrm{~min}$ to inactivate endogenous peroxidase activity. To determine CaSR and ALP expression, sections were blocked in phosphate buffered saline (PBS) containing $1 \%$ horse serum for $1 \mathrm{~h}$, followed by incubation with anti-CaSR [1:500] or anti-ALP antibodies [1:100] in $1 \%$ horse serum overnight at $4{ }^{\circ} \mathrm{C}$. Secondary antibody and further processing of slides was performed using VECTASTAIN Elite Universal ABC kit and ImmPACT DAB peroxidase substrate (Vector Laboratories, Burlingame, CA) following manufacturer's 
guidelines. To determine calcification/mineralisation, hydrated CEP sections were incubated with alizarin red solution (40 mM, pH 4.1), for $5 \mathrm{~min}$ at room temperature, or with Von Kossa: 20 min in $1 \%$ silver nitrate solution under UV light, followed by $5 \mathrm{~min}$ in $5 \%$ sodium thiosulphate, and counterstaining in haematoxylin. Proteoglycan content was visualised by staining with alcian blue (Alcian blue $8 \mathrm{GX}, \mathrm{pH} 1.0$ ) for $30 \mathrm{~min}$ and counterstained with nuclear fast red $(0.1 \%)$ for $5 \mathrm{~min}$. All sections were dehydrated by sequential alcohol concentrations and xylene, and mounted in Permount (Thermo Fisher Scientific, Waltham, MA).

\section{Isolation of human cartilaginous endplate cells}

The CEP tissue excised from human IVDs was rinsed in PBS and CEP cells were isolated by sequential digestion with $0.125 \%$ Pronase (Sigma-Aldrich, St. Louis, MO) for $30 \mathrm{~min}$ followed by $16 \mathrm{~h}$ incubation of Collagenase $[0.2 \mathrm{mg} / \mathrm{mL}]$ at $37^{\circ} \mathrm{C}$. The slurry was filtered with a $75 \mu \mathrm{m}$ nylon cell strainer and the supernatant was centrifuged at $1000 \times g$ for $10 \mathrm{~min}$. The cellular pellet was washed twice in Dulbecco's Modified Eagle Medium (DMEM) prior to seeding.

\section{Cell culturing}

Cells were maintained in DMEM calcium-free medium (Invitrogen Life Technologies, Canada), supplemented with the indicated concentrations of $\mathrm{Ca}^{2+}$ in the form of calcium chloride (Sigma-Aldrich, St. Louis, MO), 2 mM glutamine, $1 \mathrm{mM}$ sodium pyruvate, $50 \mu \mathrm{g} / \mathrm{mL}$ ascorbic acid, $1 \%$ penicillin-streptomycin and $10 \%$ heat-inactivated foetal bovine serum (FBS) (Wisent, Montreal, Canada). When not indicated, cells were maintained in $1 \mathrm{mM} \mathrm{Ca}^{2+}$. Medium was replaced every three days.

\section{Aggrecan and collagen extraction from CEP tissue}

CEPs were incubated in guanidine hydrochloride buffer (4 M guanidinium chloride, $50 \mathrm{mM}$ sodium acetate, $10 \mathrm{mM}$ ethylenediaminetetraacetic acid) for $72 \mathrm{~h}$ as previously described (Roughley and Mort, 2012). Purified tissue extracts were digested with Keratanase [0.2 mU/ $\mu \mathrm{L}$ buffer: $50 \mathrm{mM}$ Tris-HCl, $\mathrm{pH}$ 7.4] for $1 \mathrm{~h}$ at $37{ }^{\circ} \mathrm{C}$ followed by chondroitinase digestion $[10 \mathrm{mU} / \mu \mathrm{L}$ buffer: $100 \mathrm{mM}$ sodium acetate and $100 \mathrm{mM}$ Tris- $\mathrm{HCl}, \mathrm{pH}$ 7.4] for $16 \mathrm{~h}$ at $37^{\circ} \mathrm{C}$. Digestions were terminated by boiling samples for $5 \mathrm{~min}$. Aggrecan and collagen content was determined by Western blotting of extracts. Briefly, extracts were electrophoresed on 4-20\% gradient gels (Bio-Rad, Hercules, CA) and transferred to PVDF membrane. Blots were blocked in $5 \%$ bovine serum albumin (BSA) in PBS and $0.1 \%$ Tween for $1 \mathrm{~h}$, and probed with either anti-G1 [1:2000], anti-Col I [1:5000] or anti-Col II [1:5000] antibodies, for detection of aggrecan, type I and type II collagen (Col I and Col II) in antibody solution (PBS, $1 \%$ BSA and $0.1 \%$ Tween), respectively. Blots were developed by incubation with anti-rabbit-HRP secondary antibodies and Amersham ECL Prime chemiluminescent detection reagent (GE Healthcare, Piscataway, NJ). Images were captured on a Molecular Imager VersaDoc (Bio-Rad, Hercules, CA).

\section{Matrix protein synthesis and catabolic enzyme secretion in human CEP cells}

CEP chondrocytes were seeded at a density of $1.5 \times 10^{4}$ cells/well and incubated with culture medium containing the indicated concentrations of $\mathrm{Ca}^{2+}(0.5,1.0,1.5,2.5$ and $5.0 \mathrm{mM}$ ) or IL-1 $\beta$ [5 $\mathrm{ng} / \mathrm{mL}$ ] for $24 \mathrm{~h}$ or $7 \mathrm{~d}$. Conditioned media was collected $24 \mathrm{~h}$ following treatment. On day 7, wells were washed in PBS on ice (Wisent, Montreal, Canada) and accumulated matrix and cells were solubilised in RIPA (radioimmunoprecipitation assay) buffer containing protease inhibitors (Cat\# P8340, SigmaAldrich, St Louis, MO). Extracts were centrifuged at $16000 \times g$ for $5 \mathrm{~min}$ and supernatant was collected. Western blotting was performed on both conditioned media and supernatant using 4-20\% Tris-glycine gradient gels and transferring onto PVDF membrane (Bio Rad, Hercules, $\mathrm{CA})$ to determine secretion and accumulation of Col I and II, respectively. Aggrecan content was measured in supernatant from $7 \mathrm{~d}$ accumulated matrix by Western blotting using antibodies targeting the G1 domain, and the DMMB dye-binding assay (Farndale et al., 1986) was used to measure total sulphated glycosaminoglycans (GAGs), an indicator of proteoglycan content in $24 \mathrm{~h}$ conditioned media. Blots were blocked in $5 \%$ BSA in PBS and $0.1 \%$ Tween for $1 \mathrm{~h}$, and probed with either anti-G1 [1:2000], anti-Col I [1:5000] or anti-Col II [1:5000] antibodies.

For catabolic enzyme secretion, $24 \mathrm{~h}$ serum-free conditioned media $(100 \mu \mathrm{L})$ from CEP cells cultured in the indicated concentrations of $\mathrm{Ca}^{2+}(0.5,1.0,1.5,2.5$ and $5.0 \mathrm{mM}$ ) were collected and electrophoresed in 4-20\% Tris-glycine gradient gels and transferred on PVDF membrane (Bio Rad, Hercules, CA). All blots were blocked in $5 \% \mathrm{BSA}$ in PBS and $0.1 \%$ Tween for $1 \mathrm{~h}$, and probed with either anti-ADAMTS4 [1:500], anti-ADAMTS5 [1:500], or anti-MMP13 [1:2500], for detection of either ADAMTS4, ADAMTS5, and MMP-13, respectively.

\section{siRNA knock-down of CaSR}

CEP chondrocytes were seeded in 6-well plates $\left(1.5 \times 10^{4}\right.$ cells/well) and transfected with $1 \mu \mathrm{g}$ siRNA targeting the CaSR (siCaSR) (Cat\# sc-44373; Santa Cruz Biotechnology, Dallas, TX) using FuGENE HD (Promega, Madison, WI) following manufacturer's guidelines, $72 \mathrm{~h}$ prior to $\mathrm{Ca}^{2+}$ supplementation for $7 \mathrm{~d}$. Cells were also transfected with control siRNA (siCTL) (Cat\# sc-37007; Santa Cruz Biotechnology) following similar procedures. Western blotting was performed on cell lysates for detection of CaSR expression using anti-CaSR antibody.

\section{Aggrecan digestion assay}

Conditioned media from CEP chondrocytes were prepared by culturing cells in serum-free culture medium supplemented with $1.0,2.5$ or $5.0 \mathrm{mM} \mathrm{Ca}^{2+}$ in the form of calcium chloride, and incubated with purified bovine aggrecan [2 mg/mL] for $16 \mathrm{~h}$. Samples were processed as previously described (Roughley and Mort, 2012). The effect of $\mathrm{Ca}^{2+}$ on aggrecanase activity was determined by incubating recombinant ADAMTS-5 with purified aggrecan in digestion buffer $(25 \mathrm{mM}$ Tris- $\mathrm{HCl}, 75 \mathrm{mM}$ $\mathrm{NaCl}, \mathrm{pH} 7.5$ ) with different concentrations of calcium 
chloride $(0.1,0.5,1.0,1.5,2.5$ and $5.0 \mathrm{mM})$ for $6 \mathrm{~h}$ at $37{ }^{\circ} \mathrm{C}$. Digests were processed as previously described (Roughley and Mort, 2012).

\section{Bovine intervertebral disc cultures}

Caudal bovine IVDs were collected from 20-24 month steers and processed for organ culture as previously described (Parolin et al., 2010). Briefly, the connective tissue, vertebrae and bony endplates were removed. IVDs were preconditioned in DMEM culture medium containing $1 \mathrm{mM} \mathrm{Ca}^{2+}$ for $5 \mathrm{~d}$ prior to treatment. After preconditioning, IVDs were cultured in medium supplemented with either $1.0 \mathrm{mM} \mathrm{Ca}^{2+}, 2.5 \mathrm{mM} \mathrm{Ca}^{2+}$, or $2.5 \mathrm{mM} \mathrm{Ca}^{2+}+1 \mu \mathrm{M} \mathrm{CaSR}$ antagonist for 4 weeks. Media were replaced every $3 \mathrm{~d}$.

\section{Glucose diffusion assay}

Bovine IVDs were washed in PBS prior to incubation with 0.5 mM 2-(N-(7-Nitrobenz-2-oxa-1,3-diazol-4-yl)Amino)2-Deoxyglucose (2-NBDG) in glucose diffusion media (Phosphate buffered saline, calcium chloride [1 mM], magnesium chloride $[0.5 \mathrm{mM}]$, potassium chloride [5 mM] and bovine serum albumin [0.1\%]) for $48 \mathrm{~h}$ at $37^{\circ} \mathrm{C}$ and $5 \% \mathrm{CO}_{2}$. Following incubation, IVDs were washed twice in PBS and dissected to separate NP and AF tissues. Approximately $40 \mathrm{mg}$ of AF and NP dissected tissues were used for 2-NBDG extraction in guanidine hydrochloride buffer $(10 \mu \mathrm{L}$ per $\mathrm{mg}$ of tissue $)$ for $48 \mathrm{~h}$ at $4{ }^{\circ} \mathrm{C}$. Extracted samples $(100 \mu \mathrm{L})$ were measured for $520 \mathrm{~nm}$ emission intensity following excitation with $485 \mathrm{~nm}$ filtered light using a FLUOstar Omega spectrophotometer plate reader (BMG LABTECH, Ortenberg, Germany). Concentrations were determined by extrapolating from a 2-NBDG titrated standard curve.

\section{Statistical analysis}

Data were analysed by ANOVA, post hoc Dunnett's using GraphPad Prism 5.0 unless otherwise indicated. Dosedependent relations and calculations of $\mathrm{EC}_{50}$ values were also performed using GraphPad Prism.

\section{Results}

\section{Characterisation of human CEP tissue from Thompson graded IVDs}

We evaluated the biochemical analysis of human CEP extracted from donor IVDs categorised by Thompson grade (Grade 2 to 4 ). We found significant decreases in the proteoglycan content in CEP tissue from Grade 3 $(p<0.001)$ and 4 discs $(p<0.0001)$ when compared to Grade 2 (Fig. 1A). Similarly, CEP tissue showed decreases in the presence of the proform of Col I and II with grade of degeneration $(p<0.001)$, indicating reduced collagen synthesis (Fig. 1B).

Alizarin red staining demonstrated calcification of CEP that was most pronounced in Grade 4 degenerative discs (Fig. 1C). Although the mechanism(s) of CEP calcification is unclear, one necessary component is $\mathrm{Ca}^{2+}$. To determine if $\mathrm{Ca}^{2+}$ is an indicator of CEP degeneration, we measured changes in $\mathrm{CEP} \mathrm{Ca}{ }^{2+}$ content with grade of degeneration. Interestingly, $\mathrm{Ca}^{2+}$ was significantly elevated in CEP tissue from Grade $3(p<0.01)$ and Grade $4(p<0.001)$ IVDs when compared to Grade 2 (Fig. 1D), with an approximate $10 \mathrm{mM}$ median $\mathrm{Ca}^{2+}$ concentration in CEP from Grade 4 IVDs.

\section{$\mathrm{Ca}^{2+}$ decreases the synthesis of matrix proteins $\mathrm{Col}$ I,} Col II and proteoglycan in human CEP chondrocytes Increases in the levels of $\mathrm{Ca}^{2+}$ in CEP tissue with grade indicates that not all $\mathrm{Ca}^{2+}$ in the tissue is in the form of insoluble mineral. To determine if $\mathrm{Ca}^{2+}$ can stimulate the degeneration of CEP, we isolated CEP chondrocytes from Grade 2 human discs and cultured them in medium containing increasing concentrations of $\mathrm{Ca}^{2+}(0.5-5.0 \mathrm{mM}$ $\mathrm{Ca}^{2+}$ ) and determined the effect on matrix protein synthesis. Treatment of CEP chondrocytes with IL-1 $\beta$ was used as a control for its purported role in CEP and cartilage degeneration. Increasing $\mathrm{Ca}^{2+}$ in culture medium resulted in a dose-dependent inhibition in the secretion of $\mathrm{Col}$ $\mathrm{I}$ and Col II in conditioned medium of CEP cells (Fig. 2A,B). Proteoglycan release was also affected by $\mathrm{Ca}^{2+}$ as determined by measuring the content of GAG in the conditioned media of CEP treated cells (Fig. 2C). As expected, decreases in the secretion of matrix proteins by $\mathrm{Ca}^{2+}$ was also reflected in its accumulation on CEP cells. As shown in Fig. 2D and E, $\mathrm{Ca}^{2+}$ dose-dependently decreased the accumulation of matrix proteins $\mathrm{Col}$ I, Col II, and the main proteoglycan in cartilage, aggrecan (Acan). The dose-dependent relations of $\mathrm{Ca}^{2+}$ on the synthesis of $\mathrm{Col} \mathrm{I}$ and Col II were calculated from the densitometric analysis taken from blots presented in Fig. 2 A and B. The inhibitory concentration $\left(\mathrm{IC}_{50}\right)$ values for $\mathrm{Ca}^{2+}$ on the synthesis of $\mathrm{Col}$ I and Col II were $1.3 \pm 0.2 \mathrm{mM}, 1.5 \pm 0.1 \mathrm{mM}$, respectively (Fig. 2F). A similar relation was also measured for the effect of $\mathrm{Ca}^{2+}$ on the proteoglycan content in conditioned media of CEP chondrocytes presented in Fig. $2 \mathrm{C}\left(\mathrm{EC}_{50}\right.$, $2.2 \pm 0.4 \mathrm{mM})$. Taken together, these data suggest that $\mathrm{Ca}^{2+}$ plays a direct role in the synthesis of CEP matrix proteins.

\section{CaSR is present in disc cells and increases with degeneration}

The $\mathrm{IC}_{50}$ values for the effect of $\mathrm{Ca}^{2+}$ on matrix protein secretion (Fig. 2F) is in agreement with the reported effective concentration $\left(\mathrm{EC}_{50}\right)$ on the activation of $\mathrm{CaSR}$, suggesting its involvement (Brown and MacLeod, 2001). To determine if the CaSR is expressed in human CEP, we performed immunohistochemistry on Grade 2-4 CEP tissue. Indeed, the CaSR was expressed in all grades of CEP tissue; however, the intensity appeared highest in Grade 4 (Fig. 3A). To determine whether the CaSR expression was increased in Grade 4 CEP, we performed Western blotting on lysates of Grade 2-4 isolated CEP cells. Although CaSR expression was significantly increased in Grade 4 CEP cells $(p<0.05)$, a trend towards higher expression was apparent in Grade 3 cells (Fig. 3B, C).

\section{Effect of inhibition and knock-down of the CaSR on matrix protein expression}

To determine if the CaSR can regulate matrix protein synthesis in human CEP chondrocytes, we cultured cells in medium supplemented with $2.5 \mathrm{mM} \mathrm{Ca}^{2+}$ in the presence of a CaSR antagonist for $7 \mathrm{~d}$ and measured the 
A

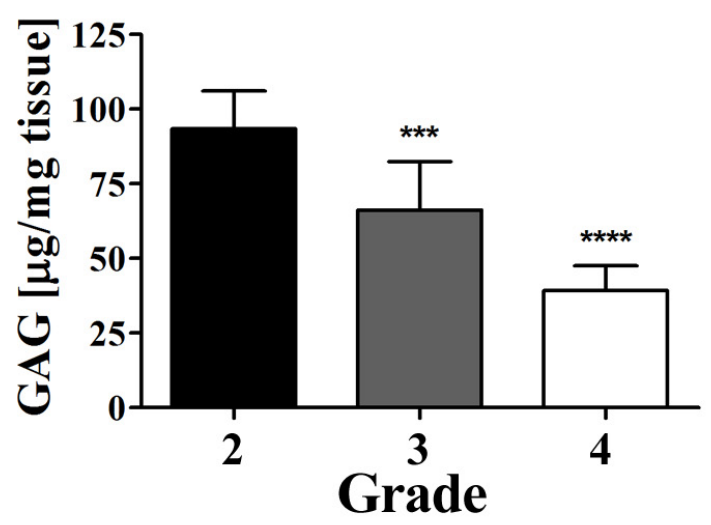

C
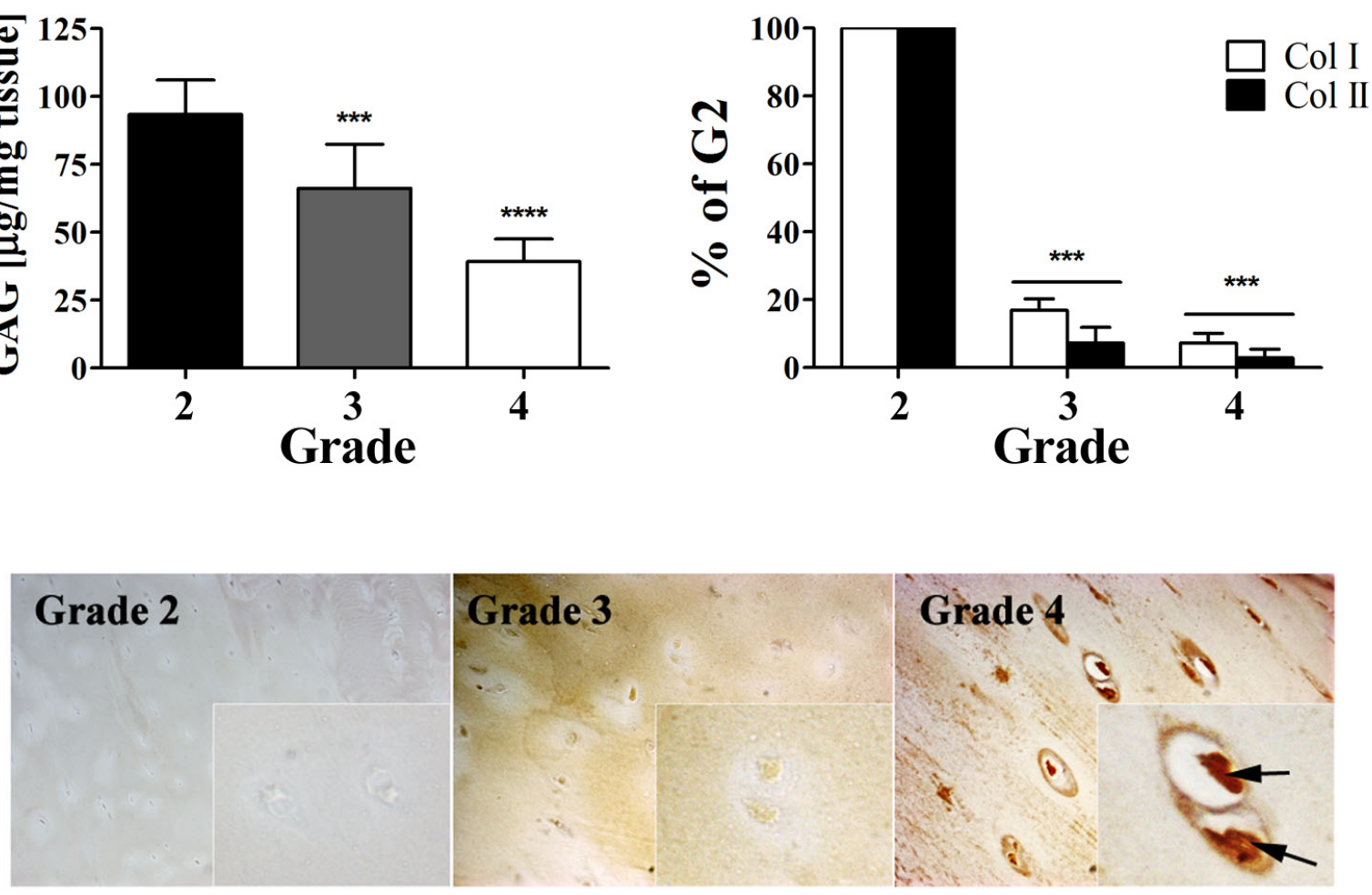

$\mathrm{C}$

D

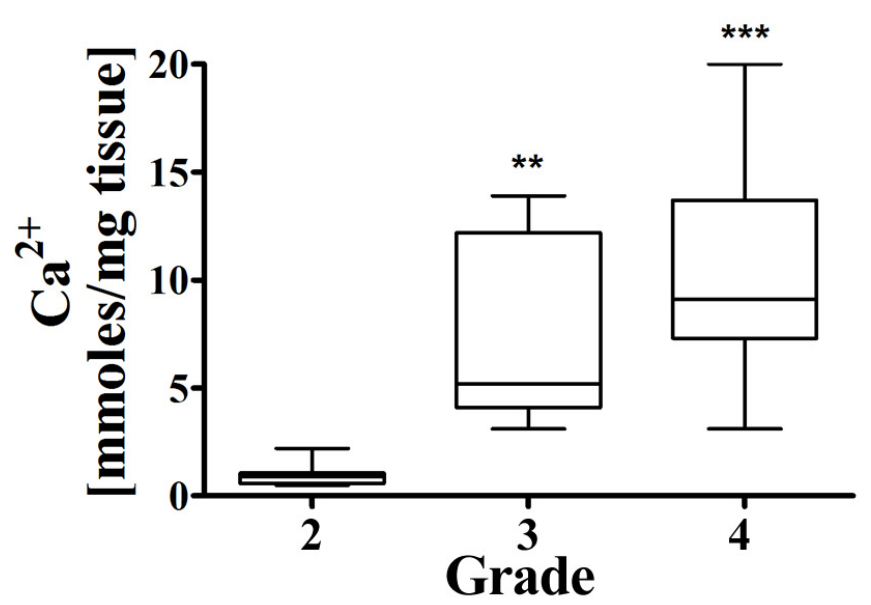

Fig. 1. Characterisation of human CEP tissue from Thompson graded IVDs for GAG, collagen and ionic Calcium $\left(\mathrm{Ca}^{2+}\right)$ content. A, DMMB assay for total glycosaminoglycan content in CEP from IVDs of Thompson grade 2, 3 and 4. Means \pm SDs. ANOVA, post-hoc Dunnett's; ***, $p<0.001$, ****, $p<0.0001$; Grade 2, $n=10$; Grade 3, $n=5$; Grade $4, n=11$. B, Newly synthesised collagen measured by densitometry from Western blots of procollagen types I and II (Col I and II) content following guanidium extraction. Values are calculated as a percent of grade 2. Means \pm SDs. ANOVA, post-hoc Dunnett's; ***, $p<0.001$. C, CEP tissue grade 2-4 was stained with alizarin red to demonstrate the appearance of calcium deposits (arrows). D, $\mathrm{Ca}^{2+}$ content in CEP tissue from graded discs. $\mathrm{Ca}^{2+}$ content is significantly elevated in CEP tissue from grade 3 and grade 4 IVDs when compared to grade 2. Whisker box plot representing min to max, line indicates median. ANOVA, post-hoc Dunnett's; **, $p<0.01, * * *, p<0.001$; Grade 2, $n=10$; Grade 3, $n=5$; Grade 4, $n=11$.

accumulation of Col I, II and aggrecan. Increasing the levels of $\mathrm{Ca}^{2+}$ in the culture medium decreased the synthesis of matrix proteins. However, the CaSR antagonist was able to dose-dependently restore the synthesis of $\mathrm{Col}$ I, II and aggrecan to levels similar to cells cultured in $1 \mathrm{mM}$ control medium (Fig. 4A,B). Conversely, when we incubated CEP chondrocytes in $1 \mathrm{mM} \mathrm{Ca}^{2+}$ and $1 \mu \mathrm{M}$ of the CaSR agonist, cinacalcet, synthesis of matrix proteins decreased significantly (Acan, $p<0.01$; Col I, $p<0.001$; Col II, $p<0.001$ ) (Fig. 4C, D).

Next, we knocked-down (KD) the CaSR by siRNA in CEP cells to determine whether loss of CaSR expression 
A

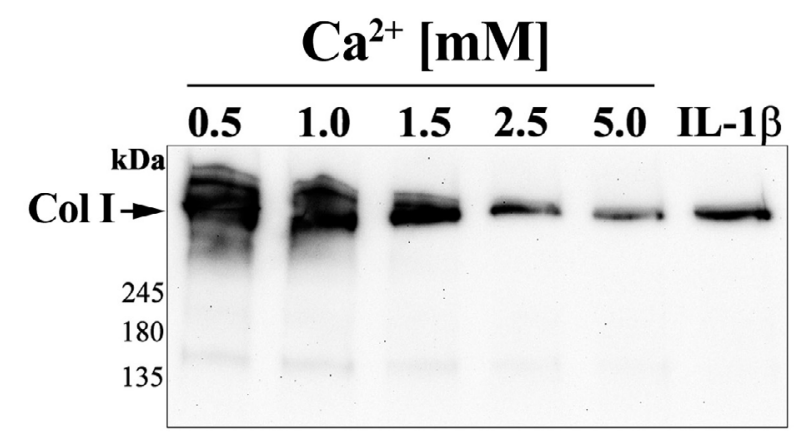

C

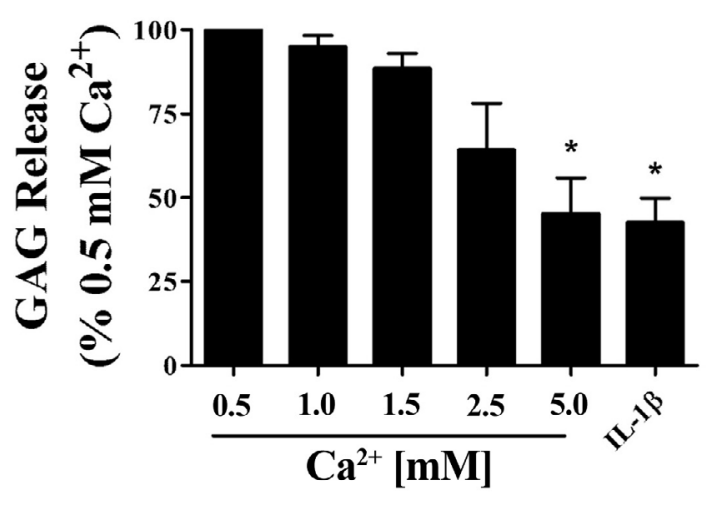

E

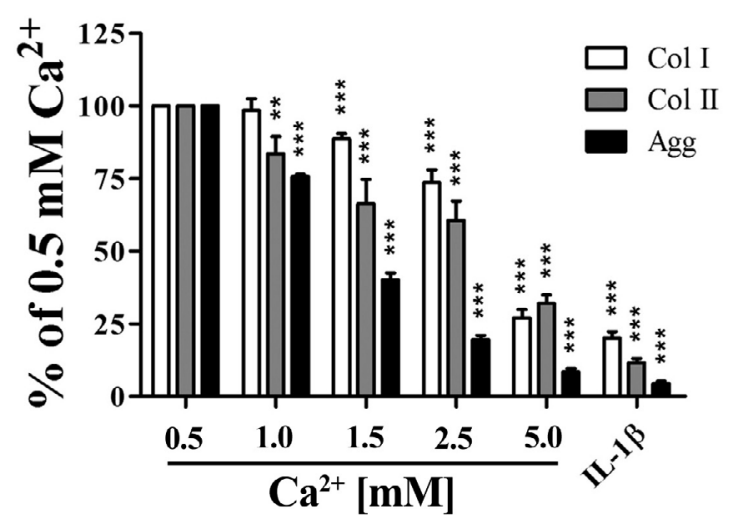

B

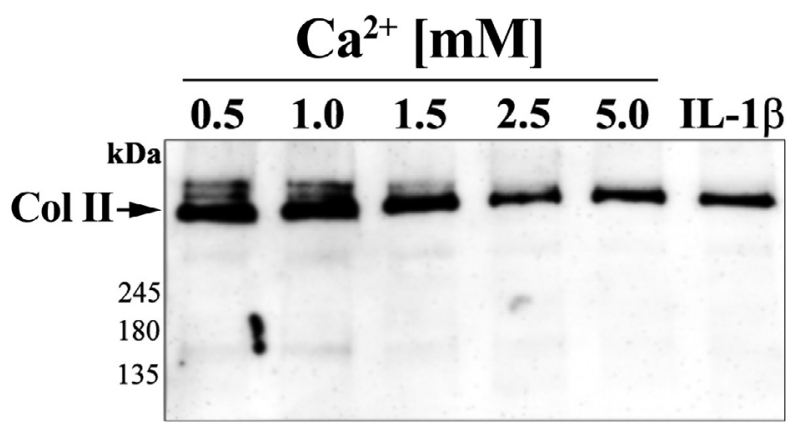

D

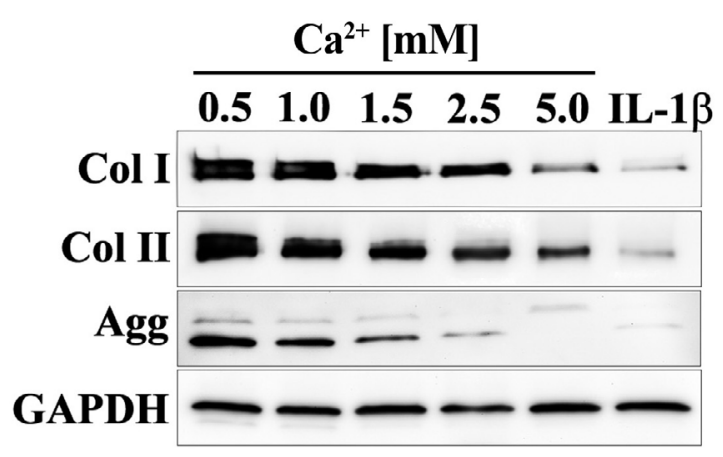

F

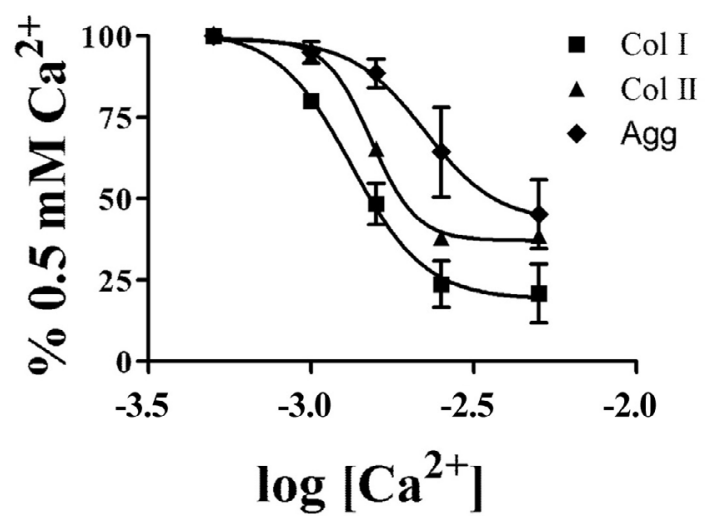

Fig. 2. Effect of $\mathrm{Ca}^{2+}$ on the synthesis of collagen and proteoglycan in human CEP chondrocytes. A $+\mathbf{B}$, Western blotting on $24 \mathrm{~h}$-conditioned media from human grade 2 CEP chondrocytes incubated in 0.5, 1.0, 1.5, 2.5 and 5.0 mM $\mathrm{Ca}^{2+}$ or IL-1 $\beta$ [5 ng/mL] and probed for types I and II collagen (Col I and II). Blots represent three independent donors. C, GAG content as a measure of proteoglycan release in 24 h-conditioned media of human grade 2 CEP chondrocytes incubated with the indicated concentrations of $\mathrm{Ca}^{2+}$ and IL-1 $\beta$ [ $\left.5 \mathrm{ng} / \mathrm{mL}\right]$. Means \pm SEMs represent three independent donors. D, Western blotting on conditioned media from human G2 CEP chondrocytes incubated in $0.5,1.0,1.5,2.5$ and $5.0 \mathrm{mM} \mathrm{Ca}{ }^{2+}$ or IL-1 $\beta[5 \mathrm{ng} / \mathrm{mL}]$ for $7 \mathrm{~d}$ and probed for types I and II collagen (Col I and II), aggrecan (Agg) and GAPDH. Blots represent grade 2 CEP chondrocytes from three donors. E, Densitometric measurements from blots presented in (D) were normalised for protein loading using GAPDH and converted to a percent of $0.5 \mathrm{mM} \mathrm{Ca}^{2+}$. CaSR dose-dependently decreases the expression of Col I, II and aggrecan. F, Densitometric analysis from blots presented in $(\mathbf{A}+\mathbf{B})$ normalised to $0.5 \mathrm{mM} \mathrm{Ca}^{2+}$ and data from $(\mathbf{C})$ were analysed using a sigmoidal dose-response curve, $\mathrm{Ca}^{2+}$ concentrations were converted to $\log$ units. Calculated $\mathrm{IC}_{50}$ values were $1.3 \pm 0.2 \mathrm{mM}$, $1.5 \pm 0.1 \mathrm{mM}$, and 2.2 \pm 0.4 , for Col I, Col II and Agg, respectively. Means $\pm \mathrm{SEMs} ; n=3$.

has similar effects on matrix protein synthesis. KD of the $\mathrm{CaSR}$ (siCaSR) resulted in an approximate $75 \%$ decrease in CaSR expression in CEP cells (Fig. 4E, F). Interestingly, aggrecan expression in CEP cells was significantly elevated following siCaSR compared to siRNA control (siCTL) in $1 \mathrm{mM} \mathrm{Ca}^{2+}$ (Fig. 4G,H). Unlike in siCTL cells, $\mathrm{Ca}^{2+}$ supplementation did not decrease the synthesis of Col I and II in siCaSR cells, but in contrast, the expression levels remained elevated in increasing $\mathrm{Ca}^{2+}$. The expression of aggrecan, however, decreased in a dose-dependent manner following increases in $\mathrm{Ca}^{2+}$ content, although levels were higher than control treated cells (Fig. 4G, H). Thus, in 
A

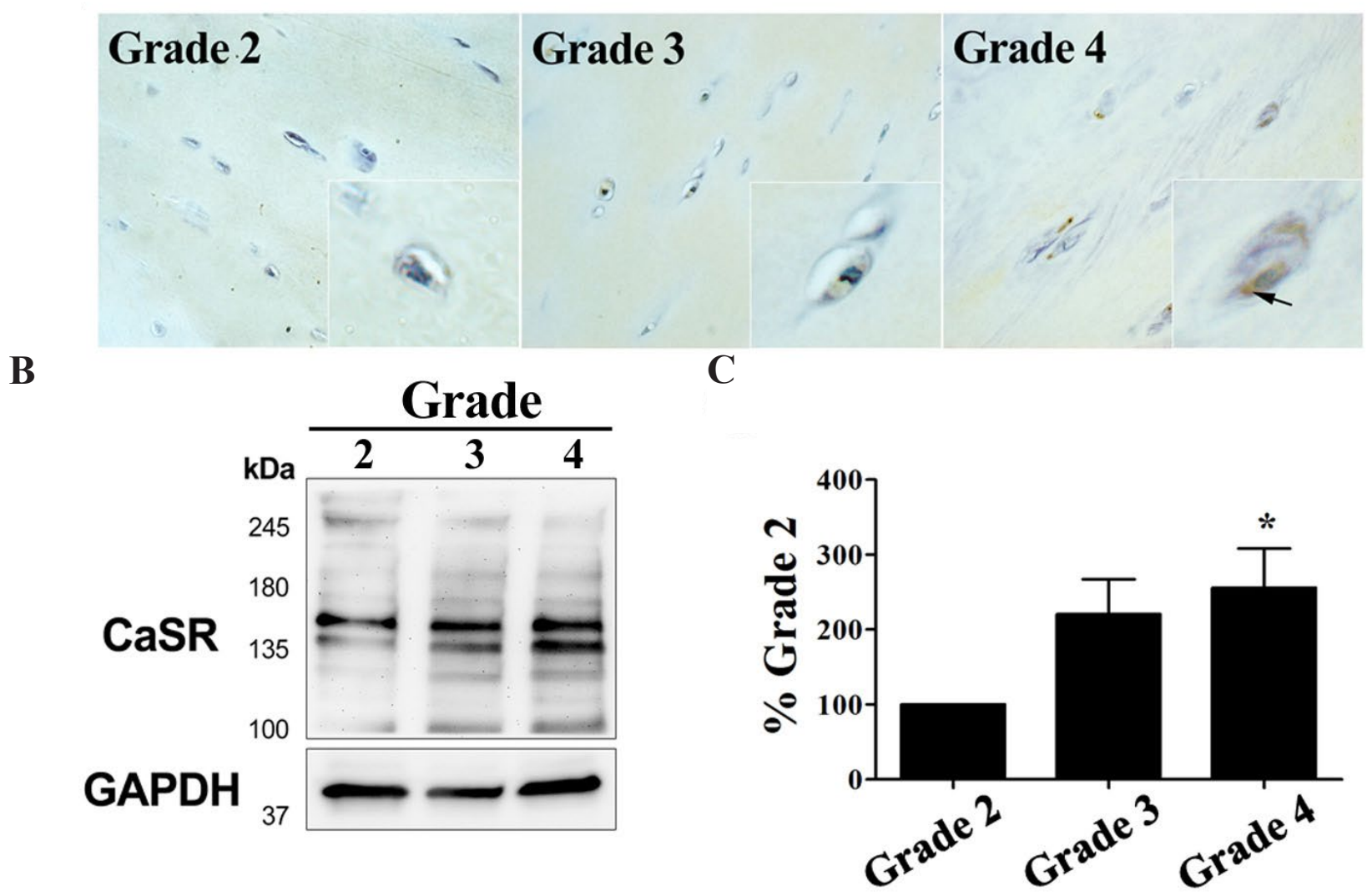

Fig. 3. CaSR expression in CEP chondrocytes from Thompson graded IVDs. A, Immunohistochemistry demonstrating up-regulation of CaSR in CEP chondrocytes with grade of degeneration (arrows). B, Western blot of CaSR (arrows indicating immature $\sim 140 \mathrm{kDa}$, and mature $\sim 160 \mathrm{kDa}$ forms) from lysates of CEP chondrocytes of Thompson grade 2, 3 and 4 IVDs. GAPDH was used as loading control. C, Densitometric analysis on blots imaged in (B). Data were calculated as a percent of grade 2. Means \pm SEMs; ANOVA, post-hoc Dunnett's; *, $p<0.05, n=3$ donors.

addition to activation of the $\mathrm{CaSR}, \mathrm{Ca}^{2+}$ may be affecting aggrecan content independently.

\section{Effect of $\mathrm{Ca}^{2+}$ on aggrecan catabolism}

To determine if $\mathrm{Ca}^{2+}$ affects the synthesis and release of catabolic enzymes in CEP chondrocytes, we measured the content of ADAMTS-4, ADAMTS-5, and MMP13 , in conditioned medium of cells supplemented with increasing concentrations of $\mathrm{Ca}^{2+}$. However, increasing the concentrations of $\mathrm{Ca}^{2+}$ did not affect the secretion of either ADAMTS-4, ADAMTS-5, or MMP-13 full-length forms (Fig. 5A).

Given that aggrecan expression is affected by high levels of $\mathrm{Ca}^{2+}$ despite $\mathrm{KD}$ of CaSR, it is possible that $\mathrm{Ca}^{2+}$ may be regulating catabolic enzyme activity resulting in enhanced aggrecan degradation. To determine if CEP-conditioned medium contained activated enzymes, we incubated purified aggrecan with media collected from CEP cells incubated in 1.0, 2.5 and $5.0 \mathrm{mM} \mathrm{Ca}^{2+}$. The degradation of aggrecan was most pronounced in conditioned medium collected from CEP cells supplemented in $5.0 \mathrm{mM} \mathrm{Ca}^{2+}$ (Fig. 5B). These data indicate that $\mathrm{Ca}^{2+}$ may be altering the activity rather than the level of catabolic enzymes. To determine if $\mathrm{Ca}^{2+}$ can have a direct effect on ADAMTS activity, we measured the cleavage of aggrecan using recombinant ADAMTS-5 with increasing concentrations of $\mathrm{Ca}^{2+}$. Increasing the concentration of $\mathrm{Ca}^{2+}$ in our assay resulted in an approximate 2 -fold increase of the G1 cleavage product of aggrecan, suggesting an enhancement in the total activity of ADAMTS-5 (Fig. 5C).

\section{$\mathrm{Ca}^{2+}$ supplementation induces degenerative changes in IVD organ cultures}

To determine if $\mathrm{Ca}^{2+}$ can induce degenerative changes in CEP tissue, we employed a bovine IVD organ culture system, a suitable model in the study of human disc degeneration. We cultured the IVDs in medium containing $1 \mathrm{mM} \mathrm{Ca}^{2+}$ (representing normal free calcium levels), $2.5 \mathrm{mM} \mathrm{Ca}^{2+}$, or $2.5 \mathrm{mM} \mathrm{Ca}^{2+}$ in the presence of a CaSR antagonist for 4 weeks. Increasing the levels of $\mathrm{Ca}^{2+}$ to $2.5 \mathrm{mM}$ in the culture medium had a significant impact on proteoglycan content in CEP tissue as demonstrated by diminished alcian blue staining when compared to IVDs cultured in $1 \mathrm{mM} \mathrm{Ca}^{2+}$ (Fig. 6A). The proteoglycan content was partially restored when IVDs incubated in $2.5 \mathrm{mM} \mathrm{Ca}^{2+}$ were co-cultured with a CaSR antagonist (Fig. 6A). Western blotting of guanidium extracted CEP tissues demonstrated a band representing full length aggrecan (Fig. 
A

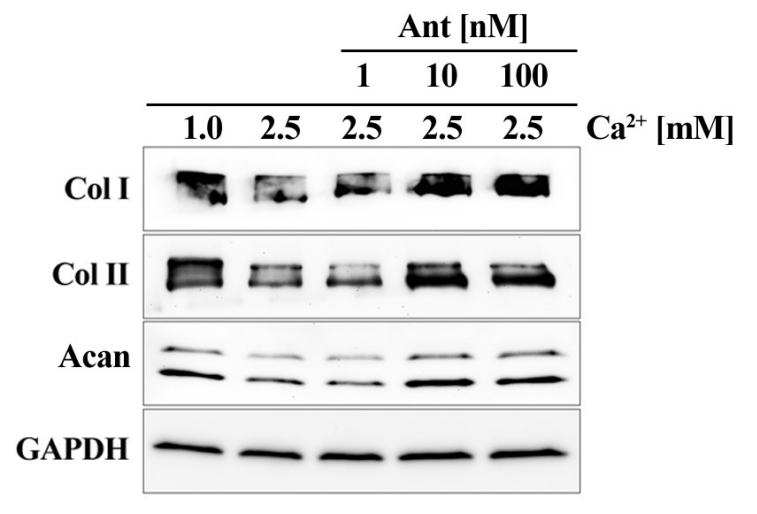

C

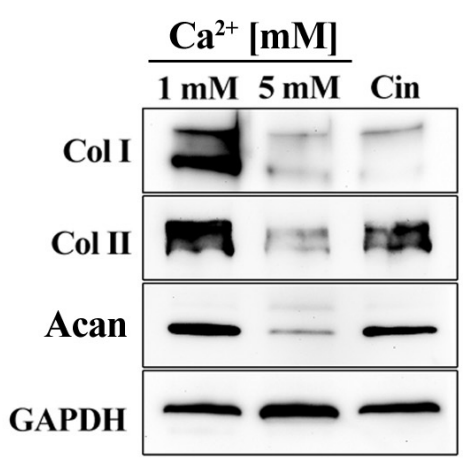

E

G
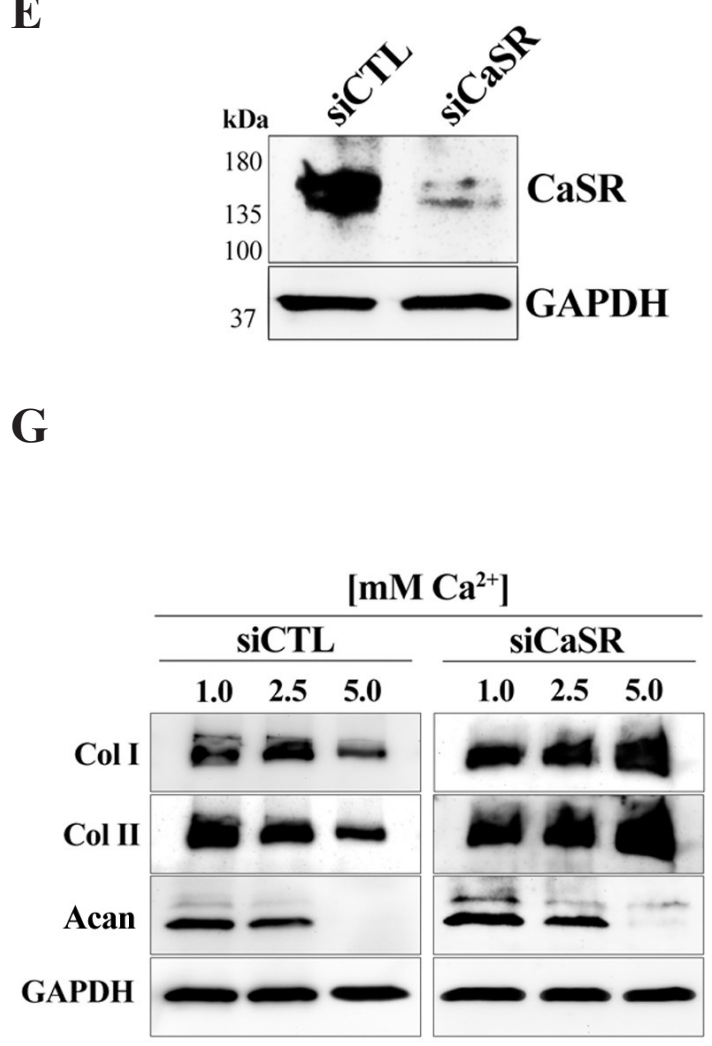

B

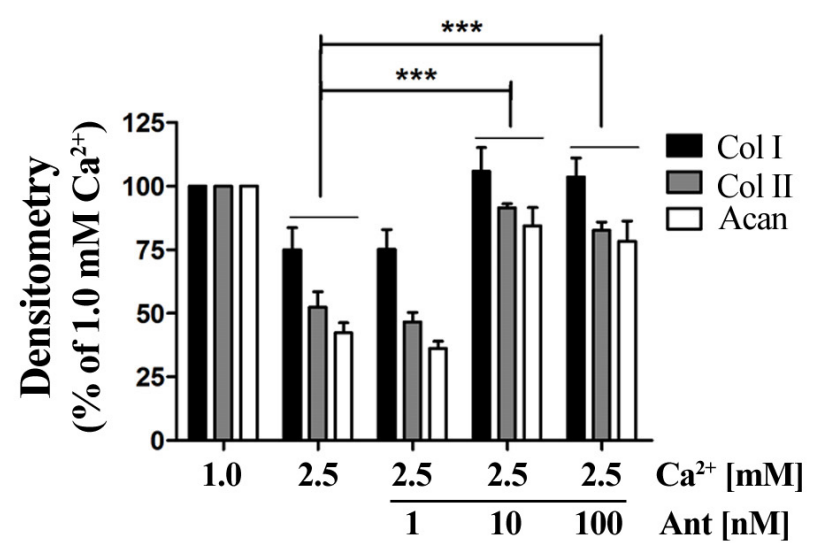

D

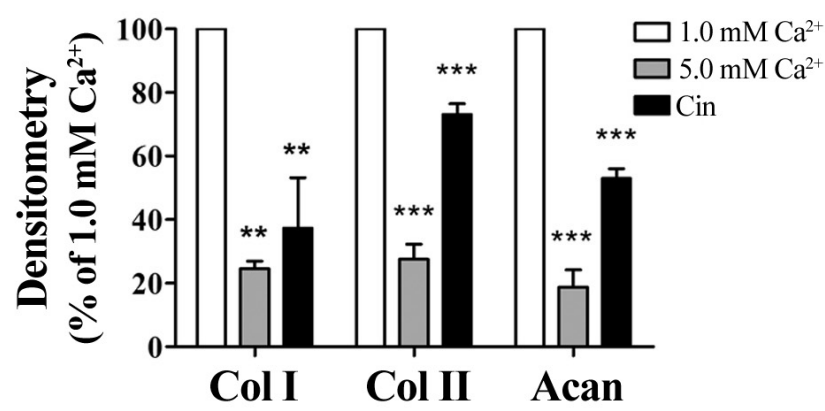

F

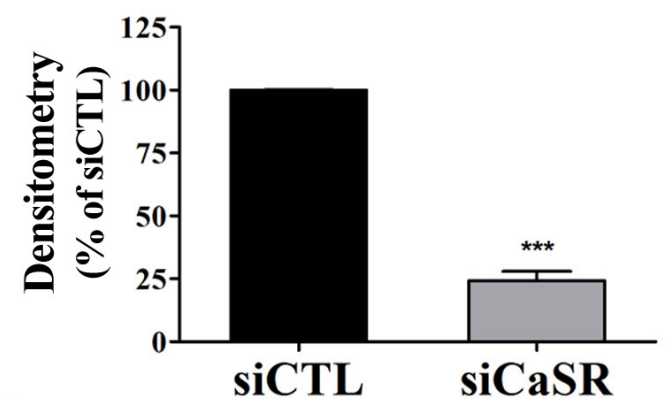

H

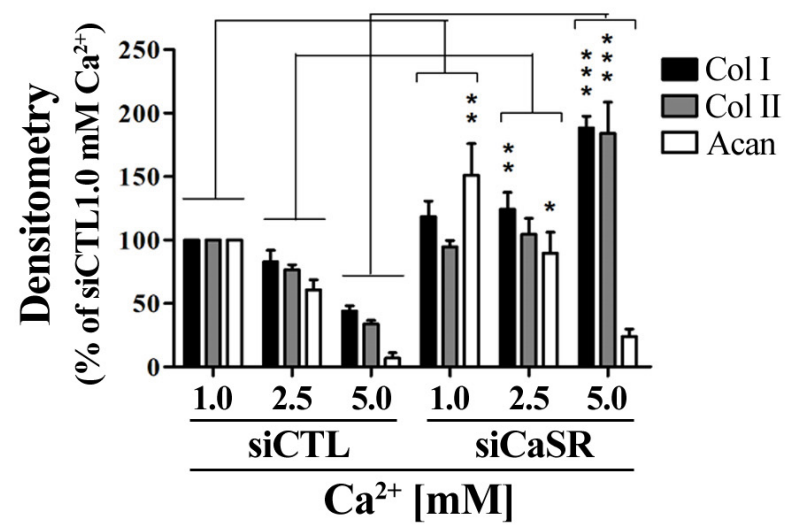


Fig. 4 (previous page). Inhibition or siRNA knock-down $(\mathrm{KD})$ of $\mathrm{CaSR}$ reverses $\mathrm{Ca}^{2+}$-induced changes in matrix protein expression. A, grade $2 \mathrm{CEP}$ chondrocytes were incubated for $7 \mathrm{~d}$ in $1.0 \mathrm{mM} \mathrm{Ca}^{2+}, 2.5 \mathrm{mM} \mathrm{Ca}^{2+}$, or $2.5 \mathrm{mM}^{2}$ $\mathrm{Ca}^{2+}$ in the presence of 1,10 or $100 \mathrm{nM} \mathrm{CaSR}$ antagonist (Ant). Lysates were probed for types I and II collagen (Col I and II), aggrecan (Acan) and GAPDH. B, Densitometry was performed on blots presented in (A) and normalised to GAPDH. Data were calculated as a percent of $1.0 \mathrm{mM} \mathrm{Ca}^{2+}$ treatment for Col I, Col II, and Agg. Means $\pm \mathrm{SEMs}$; ANOVA, post-hoc Dunnett's; ***, $p<0.001 ; n=3$. C, Representative Western blot of lysates from grade 2 CEP chondrocytes treated with $1 \mathrm{mM} \mathrm{Ca}^{2+}, 5 \mathrm{mM} \mathrm{Ca}^{2+}$ or cincalcet (Cin) $[1 \mu \mathrm{M}]$ for $7 \mathrm{~d}$ and probed for Col I, Col II, aggrecan (Acan), and GAPDH. D, Densitometric analysis of Western blots presented in (C). Data were normalised to GAPDH and calculated as a percent of $1 \mathrm{mM} \mathrm{Ca}^{2+}$. Means \pm SEMs; ANOVA, post-hoc Dunnett's; ** $p<0.01$, $* * *, p<0.001 ; n=3$. E, Western blot and densitometry $(\mathbf{F})$ of CaSR expressed in G2 CEP cells following siRNA treatment against CaSR demonstrating approximately $75 \%$ inhibition in protein expression. Means \pm SEMs; student $t$-test; ${ }^{* *}, p<0.001 ; n=3$. G, Western blot of Col I, Col II and Agg expression in CaSR knockdown (siCaSR) and control (siCTL) cells. H, Densitometry of blots presented in $(\mathbf{G})$. Intensities were normalised to GAPDH and all data were calculated as a percent of $1.0 \mathrm{mM}$ siCTL for Col I, Col II and Acan. Means \pm SEMs; ANOVA, post-hoc Dunnett's; *, $p<0.05 ; * *, p<0.01 ; * * *, p<0.001 ; n=3$.

A

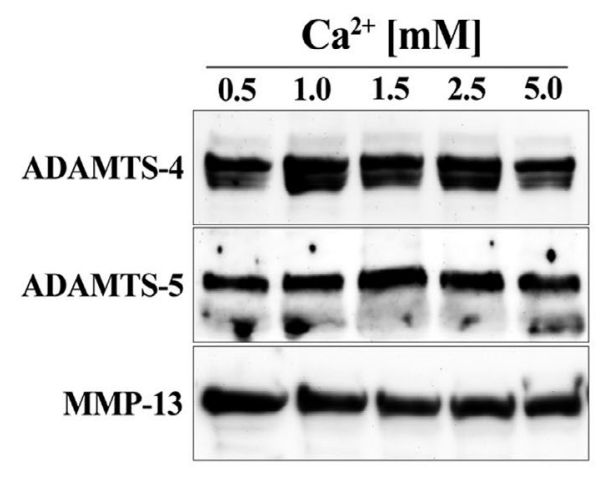

B

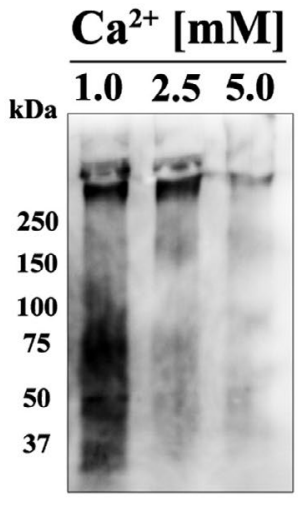

C

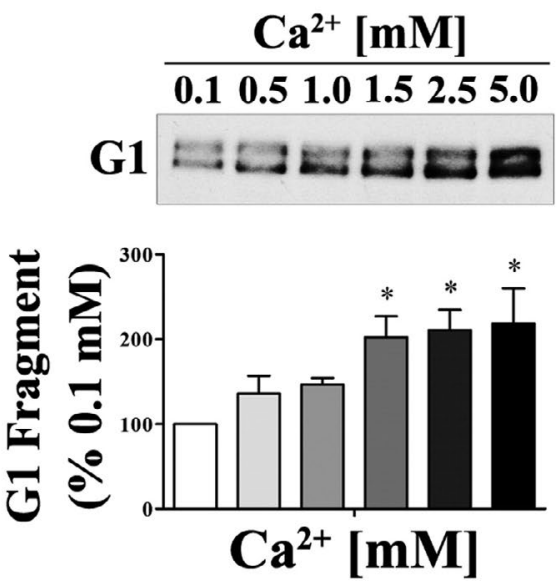

Fig. 5. Catabolic enzyme expression and the effect of $\mathrm{Ca}^{2+}$ on aggrecanase activity. Grade 2 CEP chondrocytes were cultured in serum-free medium supplemented with $0.5,1.0,1.5,2.5$ and $5.0 \mathrm{mM} \mathrm{Ca}^{2+}$ for $24 \mathrm{~h}$. A, Media were collected and probed by Western blotting for the aggrecanases ADAMTS-4 and -5, and matrix metalloproteinase MMP-13. Increasing $\mathrm{Ca}^{2+}$ in the medium did not increase the release of catabolic enzymes. $\mathbf{B}$, Western blotting of purified aggrecan treated with $\mathrm{Ca}^{2+}$-conditioned media from G2 CEP cells. C, Aggrecan and recombinant ADAMTS-5 were incubated in buffer containing increasing concentrations of $\mathrm{Ca}^{2+}[0.1-5.0 \mathrm{mM}]$ for $5 \mathrm{~h}$. Above, Western blotting for the aggrecanase G1 fragment of aggrecan. Below, densitometric analysis of blots presented above. From white bar to black: $0.1,0.5,1.0,1.5,2.5$ and $5.0 \mathrm{mM} \mathrm{Ca}^{2+}$. Data were calculated as a percent of $0.1 \mathrm{mM} \mathrm{Ca}^{2+}$. $\mathrm{Means}_{ \pm} \mathrm{SEMs}$; ANOVA, post-hoc Dunnett's; *, $p<0.05 ; n=3$.

$6 \mathbf{B} ; \geq 250 \mathrm{kDa})$, that was largely absent in IVDs cultured in $2.5 \mathrm{mM} \mathrm{Ca}^{2+}$. When IVDs were cultured in $2.5 \mathrm{mM}$ $\mathrm{Ca}^{2+}$ in the presence of the CaSR antagonist, aggrecan content was partially maintained (Fig. 6B). Elevations of $\mathrm{Ca}^{2+}$ in IVD culture medium decreased the synthesis of the proform of Col I and II in CEP, a feature of CEP degeneration; however, the addition of the CaSR antagonist suppressed the effects of $\mathrm{Ca}^{2+}$ on collagen expression in IVDs (Fig. 6C).

Water content is an important characteristic in cartilage maintenance and function, providing compressibility, homeostasis, including the diffusibility of nutrients and metabolites. Loss of water content in the CEP leads to a tissue that is more dehydrated. Proteoglycans are responsible for maintaining turgid pressure in cartilage, and aggrecan is the principal proteoglycan involved in this process. Changes in the quantity and physical properties of aggrecan affect water retention. As predicted by the decreases in aggrecan synthesis, incubation in $2.5 \mathrm{mM} \mathrm{Ca}^{2+}$ resulted in reduced water content $(p<0.001)$ (Fig. 6D), suggesting a more dehydrated and less permeable tissue; however, incubation of IVDs in $2.5 \mathrm{mM} \mathrm{Ca}^{2+}$-supplemented medium with the CaSR antagonist, significantly maintained CEP water retention.

\section{$\mathrm{Ca}^{2+}$ supplementation induces calcification in IVD organ cultures}

Calcification of the CEP is viewed as a catalyst to IVD degeneration as it impedes nutrient diffusion to the disc. To determine if $\mathrm{Ca}^{2+}$ mitigates CEP calcification we performed Von Kossa staining on CEP tissue from IVDs incubated in $1 \mathrm{mM} \mathrm{Ca}^{2+}, 2.5 \mathrm{mM} \mathrm{Ca}^{2+}$, or $2.5 \mathrm{mM} \mathrm{Ca}^{2+}$ with the CaSR antagonist (Fig. 6E). Mineralisation was evident in CEP tissue following 4 weeks incubation in $2.5 \mathrm{mM} \mathrm{Ca}^{2+}$ and 
A

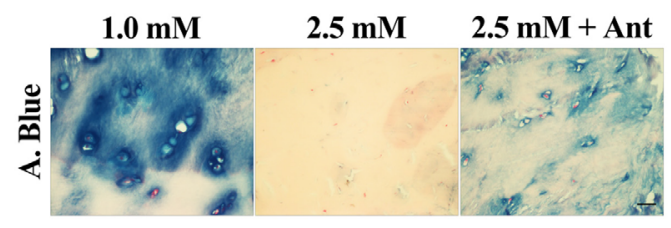

B

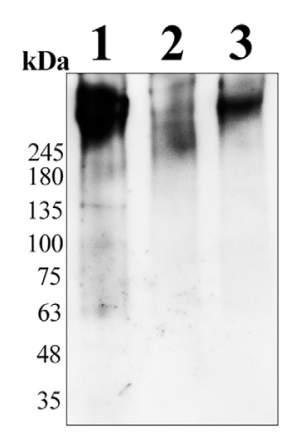

$\mathbf{E}$

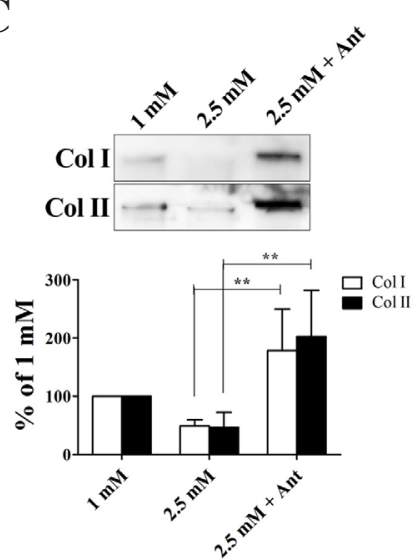

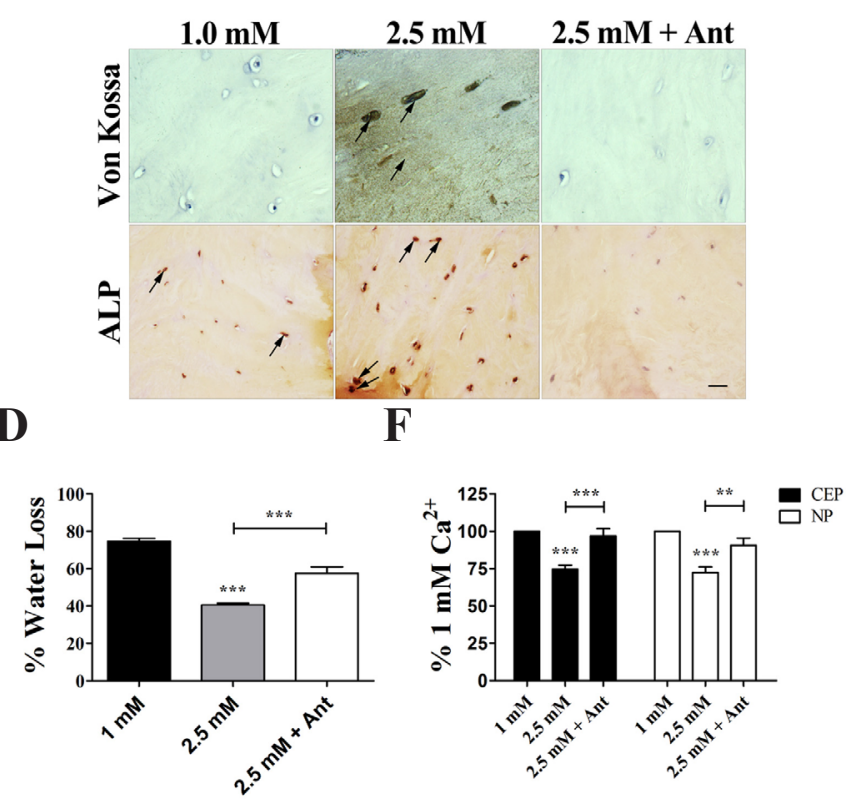

Fig. 6. Prolonged exposure to elevated $\mathrm{Ca}^{2+}$ in a bovine IVD organ model alters CEP matrix protein composition and glucose diffusion. Bovine IVDs were incubated in $1 \mathrm{mM} \mathrm{Ca}^{2+}, 2.5 \mathrm{mM} \mathrm{Ca}^{2+}$, or $2.5 \mathrm{mM} \mathrm{Ca}^{2+}+$ CaSR antagonist (Ant) $[1 \mu \mathrm{M}]$ for 4 weeks. A, Histology on CEP tissue from bovine IVDs, demonstrating the presence of proteoglycan by staining with alcian blue (A. Blue). B, Western blotting of aggrecan extracted from bovine CEP tissue $(\mathbf{1}, 1.0 \mathrm{mM}$ $\mathrm{Ca}^{2+} ; \mathbf{2}, 2.5 \mathrm{mM} \mathrm{Ca}^{2+} ; \mathbf{3}, 2.5 \mathrm{mM} \mathrm{Ca}^{2+}+$ Ant). C, Western blotting (above) and densitometry (below) of procollagen types I (Col I) and II (Col II) expression in CEP tissue (1, $1.0 \mathrm{mM} \mathrm{Ca}^{2+} ; \mathbf{2}, 2.5 \mathrm{mM} \mathrm{Ca}^{2+} ; \mathbf{3}, 2.5 \mathrm{mM} \mathrm{Ca}^{2+}+$ Ant). Means \pm SEMs; ANOVA, post-hoc Tukey's multiple comparison test, ${ }^{* *}, p<0.01 ; n=4$. D, CEP tissue was dissected and the wet and dry weights were measured and calculated as fraction of dehydration. Graph represents percent dehydration of $1 \mathrm{mM} \mathrm{Ca}^{2+}$ treated IVDs. Means \pm SEMs ; ANOVA, post-hoc Tukey's multiple comparison test; ***, $p<0.001 ; n=4$. E, Histology and immunohistochemistry on CEP tissue demonstrating mineralisation by Von Kossa staining (above) and expression of alkaline phosphatase (ALP, below), respectively. Arrows indicate mineralisation and ALP expression. F, Glucose diffusion in bovine IVDs as measured by the incorporation of 2-NBDG in CEP and NP tissue. Means \pm SEMs; ANOVA, post-hoc Tukey's multiple comparison test; **, $p<0.01 * * * ; p<0.001 ; n=3$.

not in $1 \mathrm{mM} \mathrm{Ca}^{2+}$. Inhibition of the CaSR in the presence of elevated $\mathrm{Ca}^{2+}$ was sufficient in abrogating calcification of CEP tissue. ALP, the principal enzyme involved in tissue mineralisation, was up-regulated in CEP of IVDs incubated in $2.5 \mathrm{mM} \mathrm{Ca}^{2+}$ and not in IVDs incubated in $1 \mathrm{mM} \mathrm{Ca}^{2+}$ or $2.5 \mathrm{mM} \mathrm{Ca}^{2+}$ with the CaSR antagonist (Fig. 6E).

\section{$\mathrm{Ca}^{2+}$ supplementation decreases glucose diffusion in IVD organ cultures}

The CEP behaves as a filter regulating nutrient diffusion in the disc. To determine whether the calcification induced by elevated levels of $\mathrm{Ca}^{2+}$ impairs nutrient availability to the disc, we measured the diffusion of glucose in our IVD organ culture model. Following 4 weeks of culturing in $1 \mathrm{mM} \mathrm{Ca}^{2+}, 2.5 \mathrm{mM} \mathrm{Ca}^{2+}$, or $2.5 \mathrm{mM} \mathrm{Ca}^{2+}$ with the CaSR antagonist, IVDs were incubated for $48 \mathrm{~h}$ with 2-NBDG, a fluorescent analogue of D-glucose. An approximate $25 \%$ decrease in glucose content was observed in both CEP and NP tissues in $2.5 \mathrm{mM} \mathrm{Ca}^{2+}$-incubated discs $(p<0.001)$. When the CaSR antagonist was co-incubated with $2.5 \mathrm{mM}$ $\mathrm{Ca}^{2+}$, glucose content in both the CEP and NP increased significantly and when compared to the $1 \mathrm{mM} \mathrm{Ca}^{2+}$-treated control discs (Fig. 6F).

\section{Discussion}

In the present study, we provide several lines of evidence supporting the concept that $\mathrm{Ca}^{2+}$ is involved in the degeneration of the CEP. $\mathrm{Ca}^{2+}$ content in human CEP was found to be increased with grade of degenerative disc, a finding that paralleled physical changes in the tissue. Our results corroborate previous reports on decreases in proteoglycan and collagen content in CEP tissue from degenerative discs (Antoniou et al., 1996; Bernick and Cailliet, 1982; Fields et al., 2014; Lotz et al., 2013; Roberts et al., 1989; Rodriguez et al., 2011). Although $\mathrm{Ca}^{2+}$ directly suppressed the synthesis of collagen and proteoglycan in the CEP through activation of the CaSR, it indirectly affected proteoglycan content by enhancing the activity of catabolic enzymes. Finally, we demonstrated that $\mathrm{Ca}^{2+}$ and activation of CaSR was able to induce calcification of CEP tissue partly through upregulation of ALP, the principle enzyme involved in tissue mineralisation (Whyte, 2010).

$\mathrm{Ca}^{2+}$ has been shown to affect matrix protein synthesis in chondrogenic cell types other than CEP chondrocytes. In two reports, using a transformed growth-plate chondrogenic cell line, RCJ3.1C5.18, $\mathrm{Ca}^{2+}$ was shown to mitigate the RNA expression of aggrecan and Col II, and 
increase the expression of osteogenic markers: osteopontin, osteonectin, and osteocalcin (Chang et al., 1999a; Chang et al., 2002). In these studies, activation of the CaSR was demonstrated as the main factor in transducing the $\mathrm{Ca}^{2+}$ response. Interestingly, in our study, CaSR expression was found to be up-regulated in CEP chondrocytes with grade of degeneration. Several factors may contribute to the expression of CaSR, for instance cytokines such as IL- $1 \beta$ and TNF- $\alpha$, that are up-regulated in degenerative IVDs, can drive CaSR expression (Canaff and Hendy, 2005). In addition, agonist-induced activation of CaSR has been demonstrated to increase its stability and cell-surface targeting (Grant et al., 2012; Grant et al., 2011). Both of these mechanisms, up-regulation of the CaSR by cytokines and enhanced surface targeting may contribute to the increased expression of the CaSR observed in degenerate CEP chondrocytes.

Calcification and proteoglycan content affect tissue hydration, and we demonstrate decreased water content in CEP tissue following $2.5 \mathrm{mM} \mathrm{Ca}^{2+}$ incubation in the IVD organ cultures. In addition to its role in hydrostatic loading, water content is important for disc nutrition, as both tissue dehydration and calcification are impediments to nutrient diffusion (Grunhagen et al., 2011). Concordantly, glucose diffusion into the NP was reduced in the $\mathrm{Ca}^{2+}$-treated discs, a property that could be attributed to increased mineralisation and dehydration of the CEP. Although it is unclear what constitutes $\mathrm{Ca}^{2+}$ concentrations in the nondegenerate CEP, the levels in CEP of Grade 2 discs were $\leq 1 \mathrm{mM}$, similar to serum $\mathrm{Ca}^{2+}$ levels, whereas $\mathrm{Ca}^{2+}$ content in CEP of severely degenerate discs (Grade 4) approached $10 \mathrm{mM}$. Since the reported $\mathrm{EC}_{50}$ of CaSR is $\sim 3 \mathrm{mM}$ (Tfelt-Hansen and Brown, 2005), it would imply that in non-degenerate tissue, the lower $\mathrm{Ca}^{2+}$ content has limited effect on the activity of the CaSR; however, in degenerate CEP, where $\mathrm{Ca}^{2+}$ content is elevated, the CaSR activity may be pronounced. Indeed, when we cultured IVDs in elevated $\mathrm{Ca}^{2+}$ in combination with a CaSR antagonist, mineralisation and up-regulation of ALP was abrogated, and glucose diffusion into the disc was restored.

At higher concentrations of $\mathrm{Ca}^{2+}(5 \mathrm{mM})$, the presence of aggrecan decreased, despite CaSR KD in Grade 2 human CEP cells. Aggrecan contains recognition sites for aggrecanases (ADAMTS-4,-5) and MMPs (Roughley and Mort, 2012). Although MMPs are capable of cleaving aggrecan, they are 100-fold less effective than ADAMTSs. $\mathrm{Ca}^{2+}$ has been shown to play a role in the stability and activity of MMPs, and it is predicted based on the presence of known calcium-binding sites to contribute to the structural integrity of ADAMTSs, but little is known of its functional role on enzyme activity (Shieh et al., 2008). Therefore, aggrecan content may be regulated directly by $\mathrm{Ca}^{2+}$-dependent catabolic enzyme activity, independent of CaSR and its role in aggrecan expression. Although up-regulation of catabolic enzyme levels can affect aggrecan content, we did not observe changes, at least in the expression of ADAMTS-4,-5, and MMP-13 in $\mathrm{CEP}$ chondrocytes with increasing $\mathrm{Ca}^{2+}$ concentrations. However, when we incubated purified aggrecan with $\mathrm{Ca}^{2+}$ conditioned media from CEP chondrocytes, aggrecan content decreased profoundly. These observations were further refined to reflect ADAMTS activity when we incubated aggrecan with recombinant ADAMTS-5 in increasing $\mathrm{Ca}^{2+}$ concentrations. We observed an approximate 2-fold increase in the activity of ADAMTS-5, when $\mathrm{Ca}^{2+}$ concentrations were elevated from 0.1-5.0 mM. Of note, the $\mathrm{Ca}^{2+}$ concentrations used here fall within the range observed in human CEP tissue. Given that ADAMTSs are up-regulated in degenerate CEP tissue (Chen et al., 2014; Zhang et al., 2012), minor elevations in $\mathrm{Ca}^{2+}$ could have profound effects on their activity, and hence, the integrity of aggrecan. Aggrecan is known to have a much higher rate of turnover than collagen, approximately 4-20 years versus $>100$ years, respectively (Maroudas et al., 1998; Sivan et al., 2006; Sivan et al., 2008), and in degenerative discs, aggrecan turnover can increase by two fold (Sivan et al., 2006). Aggrecan degradation appears to precede collagen degradation in the degenerate disc, and given that $\mathrm{Ca}^{2+}$ content is significantly elevated in CEP from Grade 3 degenerate discs, $\mathrm{Ca}^{2+}$ induced enhancement of aggrecanase activity may be the driving force for degradation of aggrecan in early stages of IVD degeneration. Indeed, we and others have observed decreases in the proteoglycan content of human CEP tissue with grade (Antoniou et al., 1996; Fields et al., 2014; Rodriguez et al., 2011), and, although the mechanism(s) are unclear, here we demonstrate that this could be associated with $\mathrm{Ca}^{2+}$ levels.

One question that remains unanswered is the source responsible for elevating $\mathrm{Ca}^{2+}$ in the CEP. It is unlikely to be coming from serum, as plasma $\mathrm{Ca}^{2+}$ levels are tightly regulated (1.1-1.3 $\mathrm{mM})$. A more probable source is the vertebrae, with which the CEP makes direct contact. The vertebral bodies contain a significant portion of trabecular bone, which undergoes continual remodelling. Osteoporosis is a likely cause for increased $\mathrm{Ca}^{2+}$ release in the vicinity of the CEP, as bone loss and turnover are most pronounced in the spine. Indeed, post-menopausal females who are at greater risk of developing osteoporosis (Watts, 2014) are more likely to present with severe lumbar disc degeneration than males (Margulies et al., 1996; Wang et al., 2011; Yoshimura et al., 2009). Moreover, disc degeneration associated with spondylolisthesis was approximately three times more prevalent in females who developed osteoporosis after having undergone ovariectomy, when compared to an age-matched nonovariectomised group (Imada et al., 1995). These studies suggest that accelerated bone-turnover; possibly due to development of osteoporosis, can enhance disc degeneration. Further evidence comes from in vivo studies, which have demonstrated changes in endplate and development of IVD degeneration in ovariectomised animals (Ding et al., 2014; Wang et al., 2004). Interestingly, treatment of ovariectomised rats with the anti-osteoporotic agent, alendronate, maintained bone mineral density, reduced calcification of the $\mathrm{CEP}$ and retarded lumbar disc degeneration (Luo et al., 2013). This suggests that vertebral bone loss or excessive turnover, may be a relevant source of $\mathrm{Ca}^{2+}$ that could infiltrate the CEP resulting in accelerated calcification and disc degeneration, and that anti-osteoporosis treatments may also have therapeutic potential in disc degeneration. 
The use of biologics in the regeneration of IVDs is a promising therapy for degenerate discs; however, decreases in nutrient permeability due to degeneration and calcification of the CEP may limit their potential, as the increased metabolic demand following anabolic induction of IVD cells may not be met. Therefore, any attempt to regenerate the IVD may be contingent on the structure and mineralisation of the CEP. Our current results imply that $\mathrm{Ca}^{2+}$ content in the CEP needs to be prevented from increasing above its normal range in the early stages of disc degeneration if any attempts to regenerate IVDs are to be successful.

\section{Conclusions}

We provide evidence for a direct role of $\mathrm{Ca}^{2+}$ in CEP degeneration and calcification, by modulating the activity of catabolic enzymes, and regulating the expression of matrix proteins and calcification through activation of the CaSR. Inhibiting the CaSR or reducing bone turnover to minimise $\mathrm{Ca}^{2+}$ accumulation may provide novel therapeutics in the treatment of disc disease.

\section{Acknowledgements}

The authors would like to thank our funding sources AO Spine and Canadian Institute of Health (CIHR). We would also like to thank Héma-Quebec for coordinating the retrieval of human lumbar spines through the organ donation program.

\section{References}

Alfadda TI, Saleh AM, Houillier P, Geibel JP (2014) Calcium-sensing receptor 20 years later. Am J Physiol Cell Physiol 307: C221-231.

Antoniou J, Goudsouzian NM, Heathfield TF, Winterbottom N, Steffen T, Poole AR, Aebi M, Alini M (1996) The human lumbar endplate. Evidence of changes in biosynthesis and denaturation of the extracellular matrix with growth, maturation, aging, and degeneration. Spine (Phila Pa 1976) 21: 1153-1161.

Bernick S, Cailliet R (1982) Vertebral end-plate changes with aging of human vertebrae. Spine (Phila $\mathrm{Pa}$ 1976) 7: 97-102.

Binch AL, Cole AA, Breakwell LM, Michael AL, Chiverton N, Cross AK, Le Maitre CL (2014) Expression and regulation of neurotrophic and angiogenic factors during human intervertebral disc degeneration. Arthritis Res Ther 16: 416.

Bonen DK, Schmid TM (1991) Elevated extracellular calcium concentrations induce type $\mathrm{X}$ collagen synthesis in chondrocyte cultures. J Cell Biol 115: 1171-1178.

Boos N, Nerlich AG, Wiest I, von der Mark K, Aebi M (1997) Immunolocalization of type X collagen in human lumbar intervertebral discs during ageing and degeneration. Histochem Cell Biol 108: 471-480.
Brown EM (2013) Role of the calcium-sensing receptor in extracellular calcium homeostasis. Best Pract Res Clin Endocrinol Metab 27: 333-343.

Brown EM, MacLeod RJ (2001) Extracellular calcium sensing and extracellular calcium signaling. Physiol Rev 81: 239-297.

Buckwalter JA (1995) Aging and degeneration of the human intervertebral disc. Spine (Phila Pa 1976) 20: $1307-$ 1314.

Burton DW, Foster M, Johnson KA, Hiramoto M, Deftos LJ, Terkeltaub R (2005) Chondrocyte calciumsensing receptor expression is up-regulated in early guinea pig knee osteoarthritis and modulates PTHrP, MMP-13, and TIMP-3 expression. Osteoarthritis Cartilage 13: 395404.

Canaff L, Hendy GN (2005) Calcium-sensing receptor gene transcription is up-regulated by the proinflammatory cytokine, interleukin-1beta. Role of the NF-kappaB PATHWAY and kappaB elements. J Biol Chem 280: $14177-$ 14188.

Chan WC, Sze KL, Samartzis D, Leung VY, Chan D (2011) Structure and biology of the intervertebral disk in health and disease. Orthop Clin North Am 42: 447-464.

Chang W, Dvorak M, Shoback D (2010) Assessing constitutive activity of extracellular calcium-sensing receptors in vitro and in bone. Methods Enzymol 484: 253-266.

Chang W, Tu C, Bajra R, Komuves L, Miller S, Strewler G, Shoback D (1999a) Calcium sensing in cultured chondrogenic RCJ3.1C5.18 cells. Endocrinology 140: 1911-1919.

Chang W, Tu C, Chen TH, Bikle D, Shoback D (2008) The extracellular calcium-sensing receptor (CaSR) is a critical modulator of skeletal development. Sci Signal 1: ra1.

Chang W, Tu C, Chen TH, Komuves L, Oda Y, Pratt SA, Miller S, Shoback D (1999b) Expression and signal transduction of calcium-sensing receptors in cartilage and bone. Endocrinology 140: 5883-5893.

Chang W, Tu C, Pratt S, Chen TH, Shoback D (2002) Extracellular $\mathrm{Ca}(2+)$-sensing receptors modulate matrix production and mineralization in chondrogenic RCJ3.1C5.18 cells. Endocrinology 143: 1467-1474.

Chen S, Huang Y, Zhou ZJ, Hu ZJ, Wang JY, Xu WB, Fang XQ, Fan SW (2014) Upregulation of tumor necrosis factor alpha and ADAMTS-5, but not ADAMTS-4, in human intervertebral cartilage endplate with modic changes. Spine (Phila Pa 1976) 39: E817-825.

Chevalier X, Eymard F, Richette P (2013) Biologic agents in osteoarthritis: hopes and disappointments. Nat Rev Rheumatol 9: 400-410.

David G, Ciurea AV, Iencean SM, Mohan A (2010) Angiogenesis in the degeneration of the lumbar intervertebral disc. J Med Life 3: 154-161.

DePalma MJ, Ketchum JM, Saullo T (2011) What is the source of chronic low back pain and does age play a role? Pain Med 12: 224-233.

Ding Y, Jiang J, Zhou J, Wu X, Huang Z, Chen J, Zhu $Q$ (2014) The effects of osteoporosis and disc degeneration on vertebral cartilage endplate lesions in rats. Eur Spine J 23: $1848-1855$. 
Dvorak-Ewell MM, Chen TH, Liang N, Garvey C, Liu B, Tu C, Chang W, Bikle DD, Shoback DM (2011) Osteoblast extracellular $\mathrm{Ca}^{2+}$-sensing receptor regulates bone development, mineralization, and turnover. J Bone Miner Res 26: 2935-2947.

Dvorak MM, Siddiqua A, Ward DT, Carter DH, Dallas SL, Nemeth EF, Riccardi D (2004) Physiological changes in extracellular calcium concentration directly control osteoblast function in the absence of calciotropic hormones. Proc Natl Acad Sci USA 101: 5140-5145.

Farndale RW, Buttle DJ, Barrett AJ (1986) Improved quantitation and discrimination of sulphated glycosaminoglycans by use of dimethylmethylene blue. Biochim Biophys Acta 883: 173-177.

Fields AJ, Rodriguez D, Gary KN, Liebenberg EC, Lotz JC (2014) Influence of biochemical composition on endplate cartilage tensile properties in the human lumbar spine. J Orthop Res 32: 245-252.

Grant MP, Stepanchick A, Breitwieser GE (2012) Calcium signaling regulates trafficking of familial hypocalciuric hypercalcemia $(\mathrm{FHH})$ mutants of the calcium sensing receptor. Mol Endocrinol 26: 2081-2091.

Grant MP, Stepanchick A, Cavanaugh A, Breitwieser GE (2011) Agonist-driven maturation and plasma membrane insertion of calcium-sensing receptors dynamically control signal amplitude. Sci Signal 4: ra78.

Gruber HE, Ingram JA, Cox MD, Hanley EN, Jr. (2014) Matrix metalloproteinase-12 immunolocalization in the degenerating human intervertebral disc and sand rat spine: Biologic implications. Exp Mol Pathol 97: 1-5.

Grunhagen T, Shirazi-Adl A, Fairbank JC, Urban JP (2011) Intervertebral disk nutrition: a review of factors influencing concentrations of nutrients and metabolites. Orthop Clin North Am 42: 465-477, vii.

Horner HA, Urban JP (2001) 2001 Volvo award winner in basic science studies: Effect of nutrient supply on the viability of cells from the nucleus pulposus of the intervertebral disc. Spine (Phila Pa 1976) 26: 2543-2549.

Hough TA, Bogani D, Cheeseman MT, Favor J, Nesbit MA, Thakker RV, Lyon MF (2004) Activating calciumsensing receptor mutation in the mouse is associated with cataracts and ectopic calcification. Proc Natl Acad Sci USA 101: 13566-13571.

Imada K, Matsui H, Tsuji H (1995) Oophorectomy predisposes to degenerative spondylolisthesis. J Bone Joint Surg Br 77: 126-130.

Jackson AR, Huang CY, Gu WY (2011) Effect of endplate calcification and mechanical deformation on the distribution of glucose in intervertebral disc: a 3D finite element study. Comput Methods Biomech Biomed Engin 14: 195-204.

Kang R, Li H, Ringgaard S, Rickers K, Sun H, Chen M, Xie L, Bunger C (2014) Interference in the endplate nutritional pathway causes intervertebral disc degeneration in an immature porcine model. Int Orthop 38: 1011-1017.

Kjaer P, Leboeuf-Yde C, Korsholm L, Sorensen JS, Bendix T (2005) Magnetic resonance imaging and low back pain in adults: a diagnostic imaging study of 40-year-old men and women. Spine (Phila Pa 1976) 30: 1173-1180.

Korkiakoski A, Niinimaki J, Karppinen J, Korpelainen R, Haapea M, Natri A, Tervonen O (2009) Association of lumbar arterial stenosis with low back symptoms: a cross-sectional study using two-dimensional time-of-flight magnetic resonance angiography. Acta Radiol 50: 48-54.

Kurunlahti M, Kerttula L, Jauhiainen J, Karppinen J, Tervonen O (2001) Correlation of diffusion in lumbar intervertebral disks with occlusion of lumbar arteries: a study in adult volunteers. Radiology 221: 779-786.

Lee JM, Song JY, Baek M, Jung HY, Kang H, Han IB, Kwon YD, Shin DE (2011) Interleukin-1beta induces angiogenesis and innervation in human intervertebral disc degeneration. J Orthop Res 29: 265-269.

Lotz JC, Fields AJ, Liebenberg EC (2013) The role of the vertebral end plate in low back pain. Global Spine J 3: 153-164.

Luo Y, Zhang L, Wang WY, Hu QF, Song HP, Su YL, Zhang YZ (2013) Alendronate retards the progression of lumbar intervertebral disc degeneration in ovariectomized rats. Bone 55: 439-448.

Luoma K, Riihimaki H, Luukkonen R, Raininko R, Viikari-Juntura E, Lamminen A (2000) Low back pain in relation to lumbar disc degeneration. Spine (Phila Pa 1976) 25: 487-492.

Manchikanti L, Singh V, Falco FJ, Benyamin RM, Hirsch JA (2014) Epidemiology of low back pain in adults. Neuromodulation 17 Suppl 2: 3-10.

Margulies JY, Payzer A, Nyska M, Neuwirth MG, Floman Y, Robin GC (1996) The relationship between degenerative changes and osteoporosis in the lumbar spine. Clin Orthop Relat Res 324: 145-152.

Maroudas A, Bayliss MT, Uchitel-Kaushansky N, Schneiderman R, Gilav E (1998) Aggrecan turnover in human articular cartilage: use of aspartic acid racemization as a marker of molecular age. Arch Biochem Biophys 350: 61-71.

Niinimaki J, Korkiakoski A, Parviainen O, Haapea M, Kuisma M, Ojala RO, Karppinen J, Korpelainen R, Tervonen O, Nieminen MT (2009) Association of lumbar artery narrowing, degenerative changes in disc and endplate and apparent diffusion in disc on postcontrast enhancement of lumbar intervertebral disc. MAGMA 22: 101-109.

Paajanen H, Erkintalo M, Kuusela T, Dahlstrom S, Kormano M (1989) Magnetic resonance study of disc degeneration in young low-back pain patients. Spine (Phila Pa 1976) 14: 982-985.

Paajanen H, Erkintalo M, Parkkola R, Salminen J, Kormano M (1997) Age-dependent correlation of low-back pain and lumbar disc regeneration. Arch Orthop Trauma Surg 116: 106-107.

Parolin M, Gawri R, Mwale F, Steffen T, Roughley P, Antoniou J, Jarzem P, Haglund L, Ouellet J (2010) Development of a whole disc organ culture system to study human intervertebral disc. Evid Based Spine Care J 1: 67-68.

Rajasekaran S, Babu JN, Arun R, Armstrong BR, Shetty AP, Murugan S (2004) ISSLS prize winner: A study of diffusion in human lumbar discs: a serial magnetic resonance imaging study documenting the influence of the endplate on diffusion in normal and degenerate discs. Spine (Phila Pa 1976) 29: 2654-2667. 
Risbud MV, Shapiro IM (2014) Role of cytokines in intervertebral disc degeneration: pain and disc content. Nat Rev Rheumatol 10: 44-56.

Roberts S, Menage J, Eisenstein SM (1993) The cartilage end-plate and intervertebral disc in scoliosis: calcification and other sequelae. J Orthop Res 11: 747-757.

Roberts S, Menage J, Urban JP (1989) Biochemical and structural properties of the cartilage end-plate and its relation to the intervertebral disc. Spine (Phila Pa 1976) 14: 166-174.

Roberts S, Urban JP, Evans H, Eisenstein SM (1996) Transport properties of the human cartilage endplate in relation to its composition and calcification. Spine (Phila Pa 1976) 21: 415-420.

Rodriguez AG, Slichter CK, Acosta FL, RodriguezSoto AE, Burghardt AJ, Majumdar S, Lotz JC (2011) Human disc nucleus properties and vertebral endplate permeability. Spine (Phila Pa 1976) 36: 512-520.

Rodriguez L, Cheng Z, Chen TH, Tu C, Chang W (2005) Extracellular calcium and parathyroid hormonerelated peptide signaling modulate the pace of growth plate chondrocyte differentiation. Endocrinology 146: 4597-4608.

Roughley PJ, Mort JS (2012) Analysis of aggrecan catabolism by immunoblotting and immunohistochemistry. Methods Mol Biol 836: 219-237.

Santa Maria C, Cheng Z, Li A, Wang J, Shoback D, Tu CL, Chang W (2016) Interplay between CaSR and PTH1R signaling in skeletal development and osteoanabolism. Semin Cell Dev Biol 49: 11-23.

Shieh HS, Mathis KJ, Williams JM, Hills RL, Wiese JF, Benson TE, Kiefer JR, Marino MH, Carroll JN, Leone JW, Malfait AM, Arner EC, Tortorella MD, Tomasselli A (2008) High resolution crystal structure of the catalytic domain of ADAMTS-5 (aggrecanase-2). J Biol Chem 283: 1501-1507.

Shirazi-Adl A, Taheri M, Urban JP (2010) Analysis of cell viability in intervertebral disc: Effect of endplate permeability on cell population. J Biomech 43: 1330-1336.

Sivan SS, Tsitron E, Wachtel E, Roughley PJ, Sakkee N, van der Ham F, DeGroot J, Roberts S, Maroudas A (2006) Aggrecan turnover in human intervertebral disc as determined by the racemization of aspartic acid. J Biol Chem 281: 13009-13014.

Sivan SS, Wachtel E, Tsitron E, Sakkee N, van der Ham F, Degroot J, Roberts S, Maroudas A (2008) Collagen turnover in normal and degenerate human intervertebral discs as determined by the racemization of aspartic acid. J Biol Chem 283: 8796-8801.

Stock JL, Brown RS, Baron J, Coderre JA, Mancilla E, De Luca F, Ray K, Mericq MV (1999) Autosomal dominant hypoparathyroidism associated with short stature and premature osteoarthritis. J Clin Endocrinol Metab 84: 3036-3040.

Tfelt-Hansen J, Brown EM (2005) The calcium-sensing receptor in normal physiology and pathophysiology: a review. Crit Rev Clin Lab Sci 42: 35-70.

Thompson JP, Pearce RH, Schechter MT, Adams ME, Tsang IK, Bishop PB (1990) Preliminary evaluation of a scheme for grading the gross morphology of the human intervertebral disc. Spine (Phila Pa 1976) 15: 411-415.
Tokuda O, Okada M, Fujita T, Matsunaga N (2007) Correlation between diffusion in lumbar intervertebral disks and lumbar artery status: evaluation with fresh blood imaging technique. J Magn Reson Imaging 25: 185-191.

Urban JP, Smith S, Fairbank JC (2004) Nutrition of the intervertebral disc. Spine (Phila Pa 1976) 29: 2700-2709.

Visuri T, Ulaska J, Eskelin M, Pulkkinen P (2005) Narrowing of lumbar spinal canal predicts chronic low back pain more accurately than intervertebral disc degeneration: a magnetic resonance imaging study in young Finnish male conscripts. Mil Med 170: 926-930.

Wang T, Zhang L, Huang C, Cheng AG, Dang GT (2004) Relationship between osteopenia and lumbar intervertebral disc degeneration in ovariectomized rats. Calcif Tissue Int 75: 205-213.

Wang YX, Griffith JF, Ma HT, Kwok AW, Leung JC, Yeung DK, Ahuja AT, Leung PC (2011) Relationship between gender, bone mineral density, and disc degeneration in the lumbar spine: a study in elderly subjects using an eight-level MRI-based disc degeneration grading system. Osteoporos Int 22: 91-96.

Watts NB (2014) Insights from the global longitudinal study of osteoporosis in women (GLOW). Nat Rev Endocrinol 10: 412-422.

Whyte MP (2010) Physiological role of alkaline phosphatase explored in hypophosphatasia. Ann N Y Acad Sci 1192: 190-200.

Wu S, Palese T, Mishra OP, Delivoria-Papadopoulos M, De Luca F (2004) Effects of $\mathrm{Ca}^{2+}$ sensing receptor activation in the growth plate. FASEB J 18: 143-145.

Yoshimura N, Muraki S, Oka H, Mabuchi A, En-Yo Y, Yoshida M, Saika A, Yoshida H, Suzuki T, Yamamoto S, Ishibashi H, Kawaguchi H, Nakamura K, Akune T (2009) Prevalence of knee osteoarthritis, lumbar spondylosis, and osteoporosis in Japanese men and women: the research on osteoarthritis/osteoporosis against disability study. J Bone Miner Metab 27: 620-628.

Zhang Q, Huang M, Wang X, Xu X, Ni M, Wang Y (2012) Negative effects of ADAMTS-7 and ADAMTS-12 on endplate cartilage differentiation. J Orthop Res 30: 1238-1243.

\section{Discussion with Reviewers}

Reviewer I: What mechanisms would you suggest we could target the raised calcium levels in the disc?

Authors: If elevated $\mathrm{Ca}^{2+}$ content in the disc is indeed the result of diffusion gradients generated from vertebral bone turnover, then regulating bone resorption may be a means of limiting $\mathrm{Ca}^{2+}$ infiltration. The use of bisphosphonates may be one mechanism of targeting the raised $\mathrm{Ca}^{2+}$ levels, as these drugs affect osteoclast activity thereby reducing bone absorption. Another mechanism that is perhaps more radical, is the use of chelating agents such as ethylenediaminetetraacetic acid (EDTA). These agents are typically administered when heavy metal poisoning is suspected but could possibly be used to limit $\mathrm{Ca}^{2+}$ availability by injection in the disc. 
Reviewer I: Do you think the raised calcium levels observed in the disc will also affect the homeostasis of the $\mathrm{NP}$ and AF as well as the CEP?

Authors: Yes. Work to be published elsewhere from our lab shows that elevated levels of free calcium adversely affect the NP and AF function.

Reviewer II: Do the authors think that a control with a dose response of another salt would be valid?

Authors: Yes, however, this would depend on the salt in question. For instance, some salts at high enough concentrations can activate CaSR and include: magnesium $\left(\mathrm{Mg}^{2+}\right)$, strontium $\left(\mathrm{Sr}^{2+}\right)$, gadolinium $\left(\mathrm{Gd}^{3+}\right)$ and lanthanum $\left(\mathrm{La}^{3+}\right)$ (Filopanti et al., 2013). Another issue in choosing a control salt is whether similar to $\mathrm{Ca}^{2+}$, it doesn't activate an extracellular receptor. An interesting example is zinc $\left(\mathrm{Zn}^{2+}\right) . \mathrm{Zn}^{2+}$ has been shown to activate the G-protein coupled receptor GPR39 at low micromolar concentrations (Hershfinkel et al., 2001; Holst et al., 2007).

Reviewer II: Calcium cellular flux is tightly controlled. How do the authors think the $\mathrm{Ca}$ is affecting the expression of the ADAMTS proteins, for example?

Authors: Yes, cellular $\mathrm{Ca}^{2+}$ is tightly controlled but we don't think that $\mathrm{Ca}^{2+}$ is regulating the expression of ADAMTS enzymes. Our data indicate that extracellular $\mathrm{Ca}^{2+}$ can alter ADAMTS enzymatic activity. ADAMTS proteins contain several $\mathrm{Ca}^{2+}$-binding sites purported for being important in enzyme structure-activity (Shieh et al., 2008).

Reviewer III: It will be informative if authors could elaborate on phosphate ion concentrations seen in endplate during degeneration. Since elevated calcium is known to promote Pi mediated apoptosis of terminally mature hypertrophic chondrocyte, is there a possibility that such a mechanism may be at play in endplate and result in endplate sclerosis. I encourage authors to discuss this point in discussion.

Authors: This is an interesting point and it is possible that similar to chondrocytes, $\mathrm{Pi}$ along with $\mathrm{Ca}^{2+}$ may regulate the maturation and apoptosis of CEP cells (Mansfield et al., 2003; Kim et al., 2010). In a previous report, we have demonstrated that $\mathrm{Pi}$ is elevated in CEP tissue from degenerative versus control IVDs (Hristova et al., 2011). Although not investigated here, it would not be surprising if similar mechanisms are at play in the CEP where elevations in $\mathrm{Ca}^{2+}$ and Pi serve to regulate CEP cell homeostasis and sclerosis of the tissue.

\section{Additional References}

Filopanti M, Corbetta S, Barbieri AM Spada A (2013) Pharmacology of the calcium sensing receptor. Clin Cases Miner Bone Metab 10: 162-165.

Hershfinkel M, Moran A, Grossman N, Sekler I (2001) A zinc-sensing receptor triggers the release of intracellular $\mathrm{Ca}^{2+}$ and regulates ion transport. Proc Natl Acad Sci USA 98: 11749-11754.

Holst B, Egerod KL, Schild E, Vickers SP, Cheetham S, Gerlach LO, Storjohann L, Stidsen CE, Jones R, BeckSickinger AG, Schwartz TW (2007) GPR39 signaling is stimulated by zinc ions but not by obestatin. Endocrinology 148: $13-20$.

Hristova GI, Jarzem P, Ouellet JA, Roughley PJ, Epure LM, Antoniou J, Mwale F (2011) Calcification in human intervertebral disc degeneration and scoliosis. J Orthop Res 29: 1888-1895.

Kim HJ, Delaney JD, Kirsch T (2010) The role of pyrophosphate/phosphate homeostasis in terminal differentiation and apoptosis of growth plate chondrocytes. Bone 47: 657-665.

Mansfield K, Pucci B, Adams CS, Shapiro IM (2003) Induction of apoptosis in skeletal tissues: phosphatemediated chick chondrocyte apoptosis is calcium dependent. Calcif Tissue Int 73: 161-172.

Editor's note: The Scientific Editor responsible for this paper was Brian Johnstone. 